\title{
Measuring Electronic Learning Readiness of Art Students
}

\section{A.Rasouli,Z.Rahbarnia (Ph.D), M.Attaran (Ph.D)}

Abstract: Our goal was to investigate readiness of art students in application of e-learning. This is a Descriptive- Survey research. Three hundred and forty-seven students of Alzahra University, Tarbiat Modares University, University of Tehran and Art University in 2013-2014 were selected by multistage cluster sampling and via Morgan Table. Their readiness for Elearning application was assessed by researcher-developed questionnaire. Data analysis is done by indexes of Descriptive statistics and One-Sample T-test. The results showed that a significant relationship was found between readiness of undergraduate students, graduate Students and post-graduate students to apply E-learning, but there was no significant relationship between the other variables of research (Sex, University and Field of Study). Results revealed that Art students were located in Moderate level of readiness for applying E-learning.

Key Words: E-learning, Art Students, Learning Readiness, University.

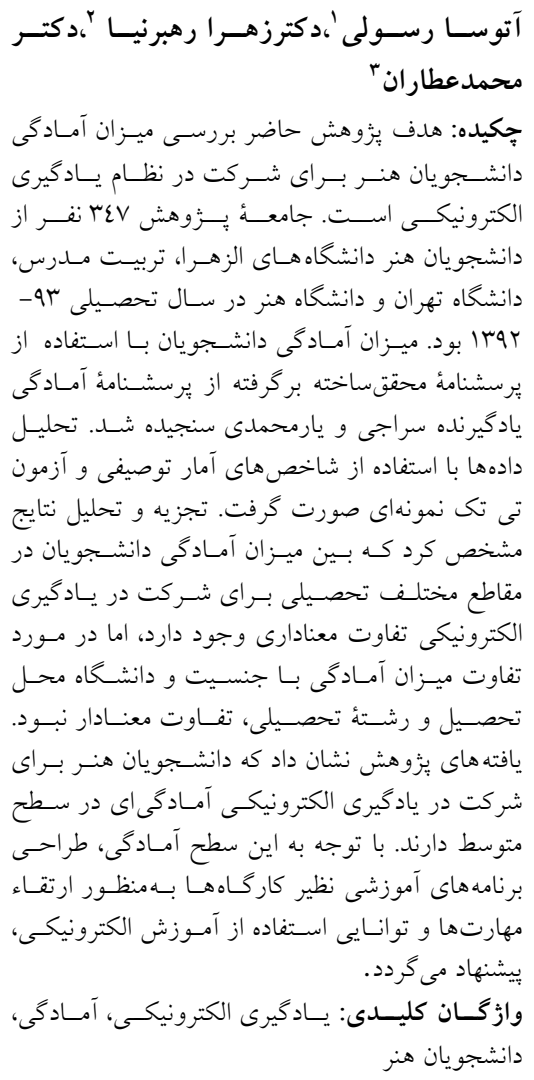

رايانامه: atousarasouli@yahoo.com

$$
\begin{aligned}
& \text { ا. دانشجوى دكترى دانشگاه الزهرا } \\
& \text { r. بانشيار دانشخاه الزهرا }
\end{aligned}
$$

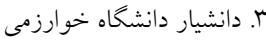

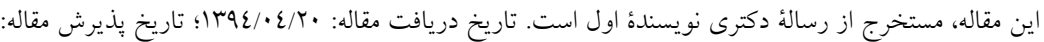




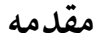

مهم ترين هدف در هر نوع آموزشى دستيابى به آموزش با كيفيت و غنى است. يكى از

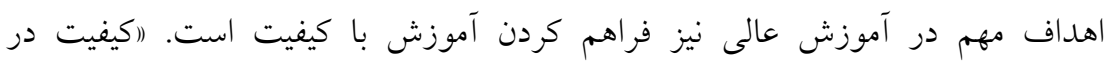

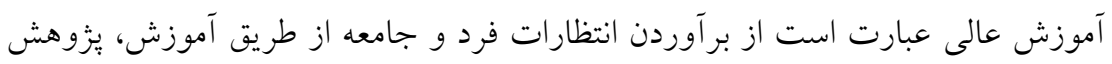

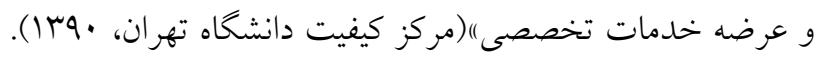

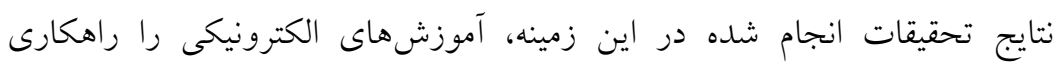

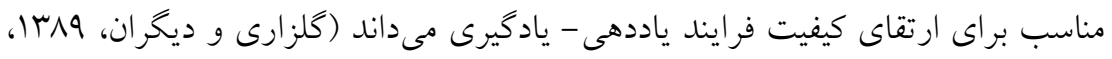

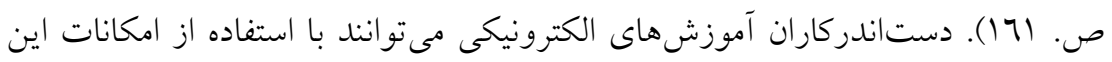
نظام آموزشى، شرايط يادگيرى با كيفيت را براى دانشجويان فراهم كنند (سراجى، r rar

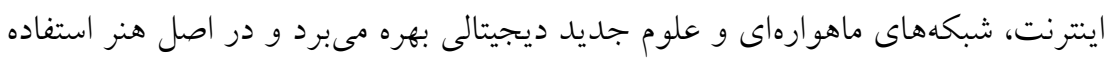

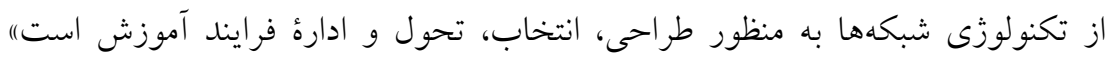

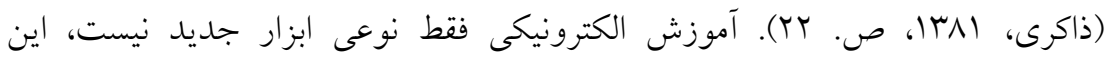

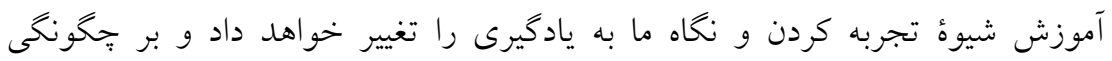

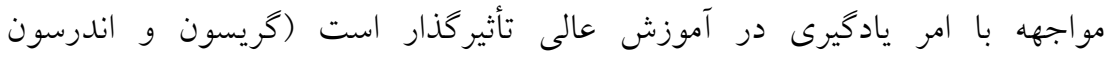

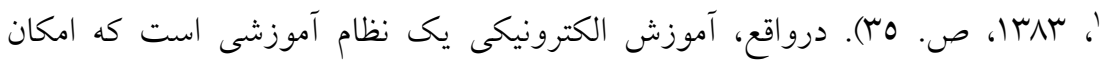

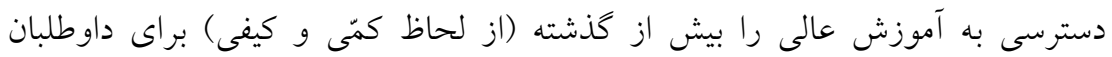

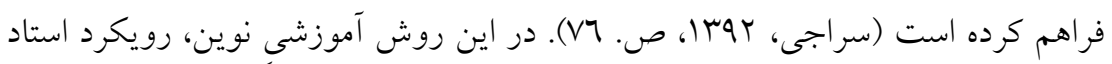

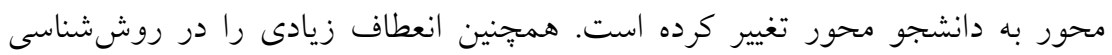

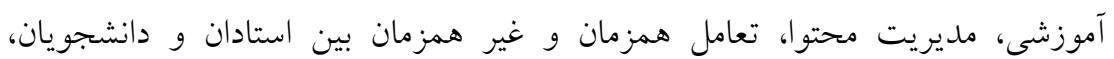
سازماندهى و ساختار دوره، طرحهاى آموزشى و بالاخره ارزيابى دانشجو ارائه مى كند. همئ.

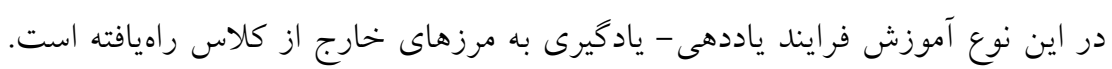

\section{Gerreson \& Anderson}


بدين ترتيب محدودههاى فيزيكى آموزش از بين رفته و عرضه و يادگيرى دانش در هر

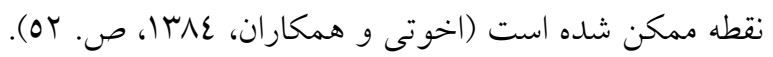

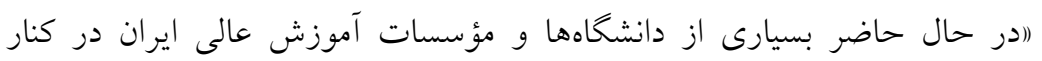

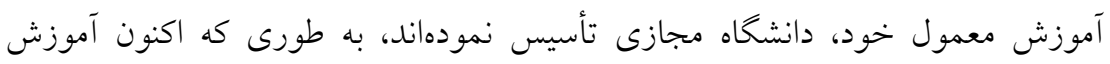
الكترونيكى در ايران به يكى از انواع تحصيلات رسمى تبديلشده است و هرسال

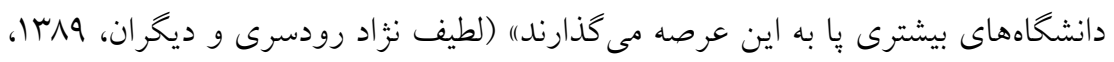

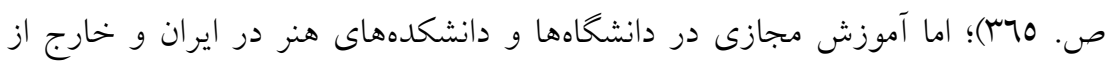

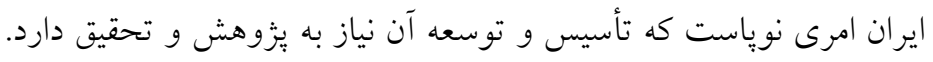

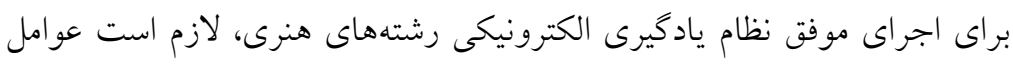

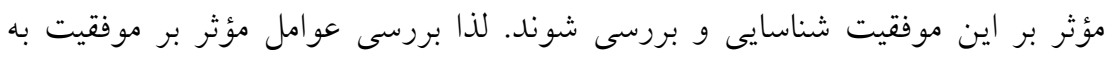

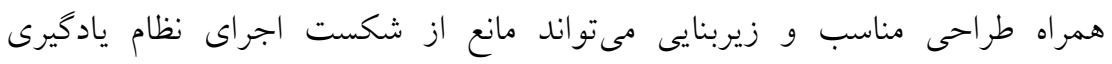

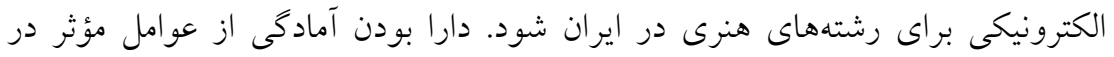

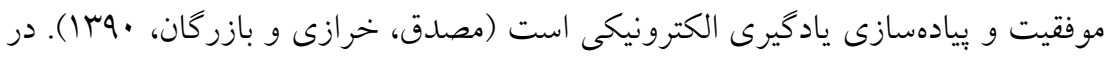

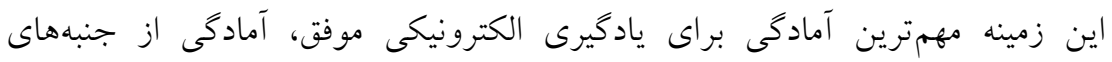
دانشجويان، اساتيد و فناورى است و نخرش اين افراد، به خصوص دانئ دانشجويان، به همراه

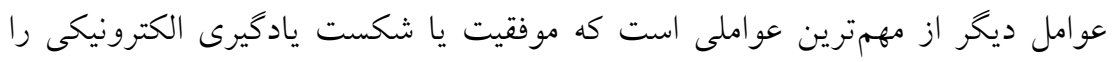

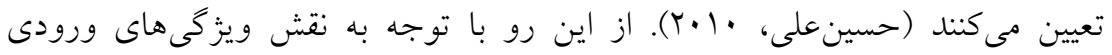

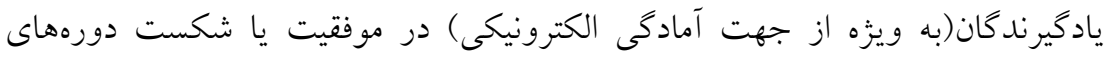

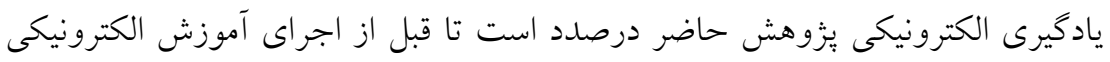

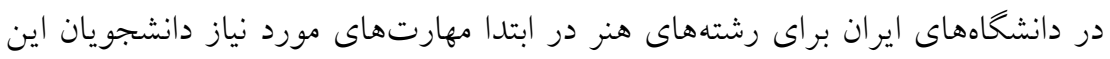
رشته ها را بسنجد.

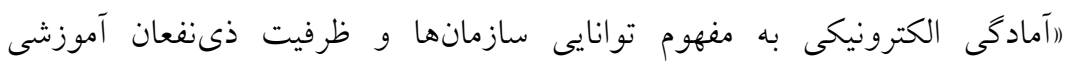

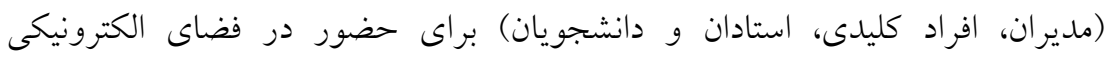




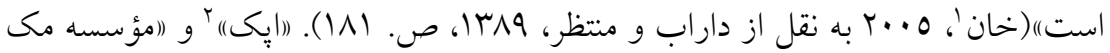

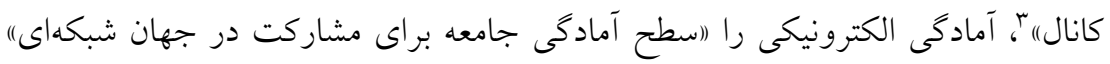

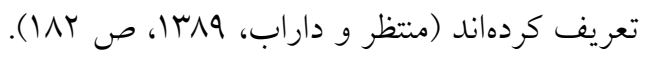

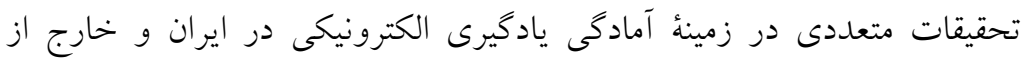
ايران انجامشده است. اين تحقيقات را مىتوان به سه كروه تقسيم كرد؛ تعدادى به دئه دنبال

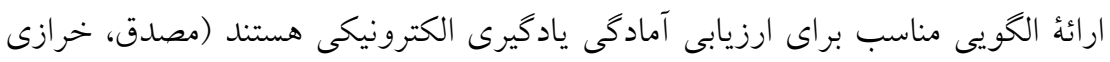

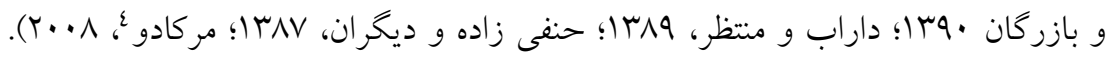

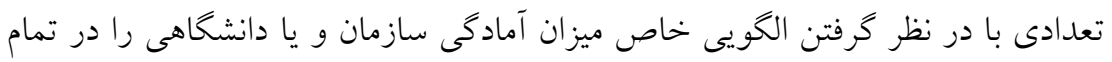

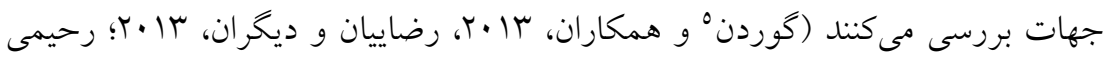

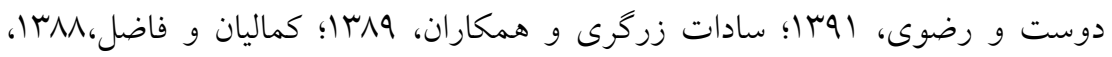

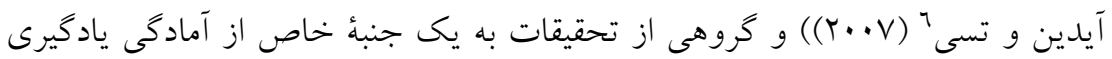

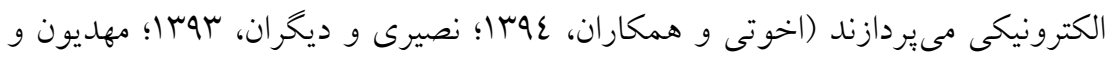
همكاران،

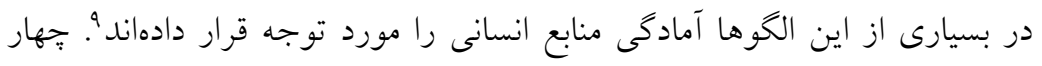

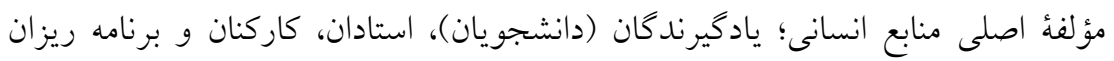

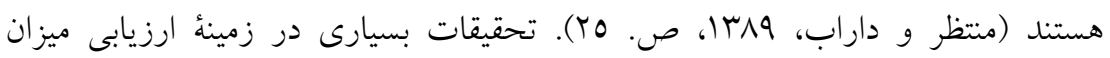

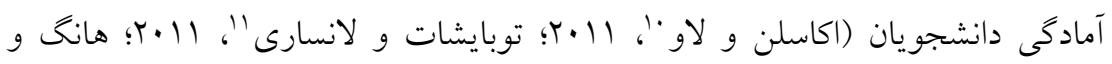

\section{Badrul. H. Khan}

2. Asian Pacific Economic Cooperation

3. Mc Connell

4.Cecilia A. Mercado

5. Gordon

6. Aydin C.H. and Tasci D

7. Sadik A

8. Jariangprasert, $\mathrm{N}$

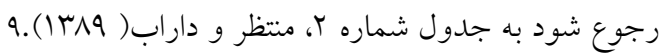

10.Akaslan, D. \& Law, E.L.C

11. Tubaishat, A \& Lansari, A 


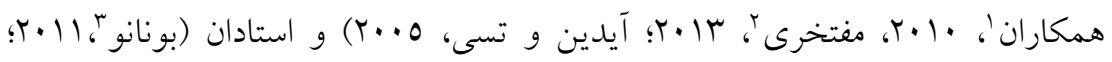

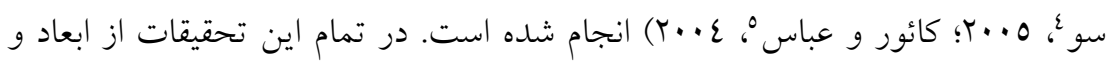

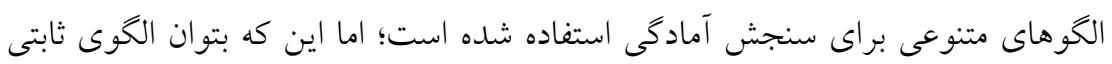

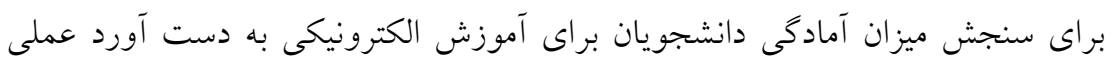

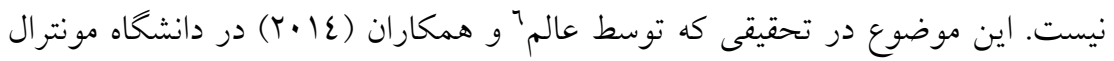

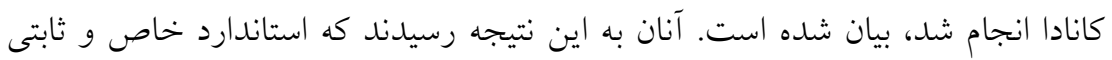

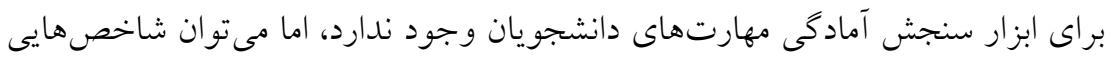

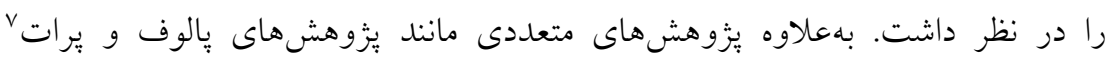

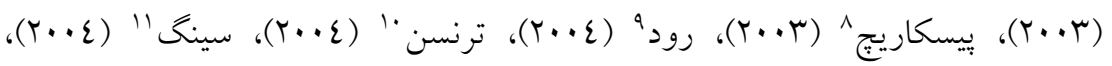

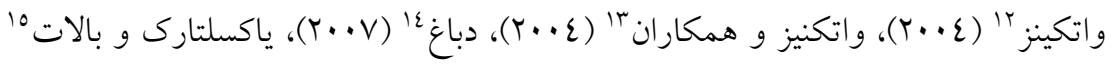

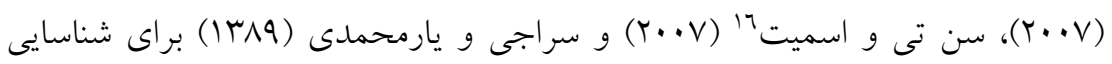

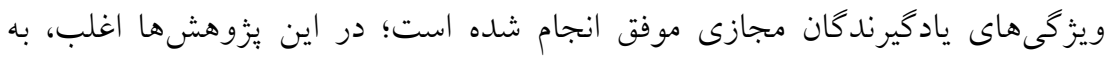

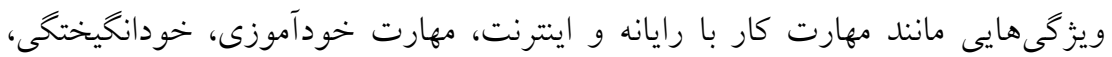
داشتن تفكر حل مسئله و انتقادى، مهارت مديريت زمان، علاقهمندى به يادگيرى،

1. Hung, M.L. Chou, C.H., Chen, C., \& Own, Z.Y.

2.Moftakhari

\section{Bonanno}

4.So.K.K.T.

5. Kaur \& Abas

6.Farid alem

7. Palloff, R. \& Pratt, K.

8. Piskurich

9. Rhode.J.F

10. Tronsen.N.H

11. Harvey Singh

12. Ryan Watkins

13. Ryan Watkins;Doug Leigh;Don Triner

14. Dabbagh

15. Yukselturk. E. \& Bulut, S.

16. Santy \& Smith 
مهارت خود راهبرى، توان ارتباط با گروه، خودارزيابى، قدرت يرسشكرى، مهارت

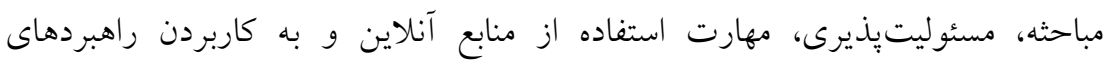

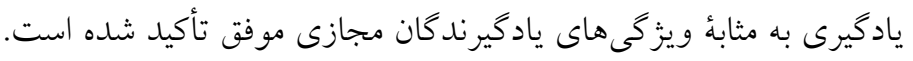

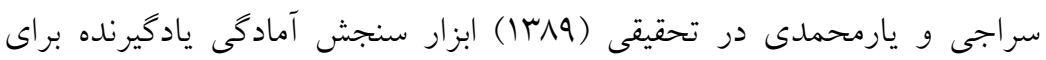

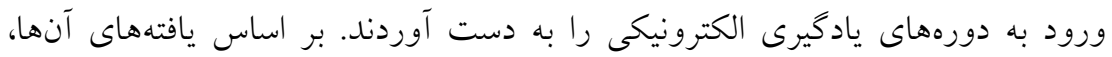

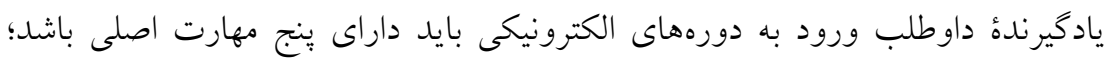

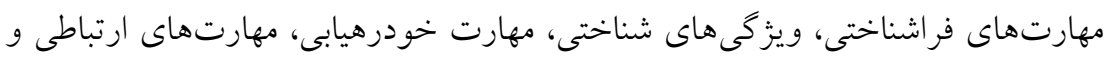

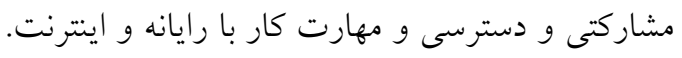

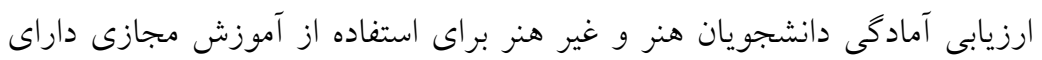

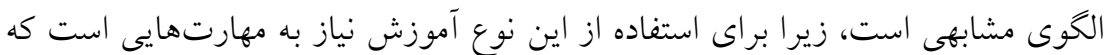

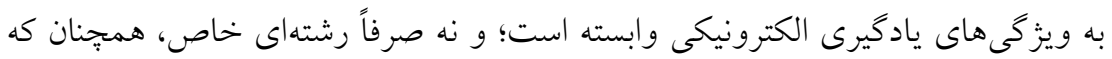

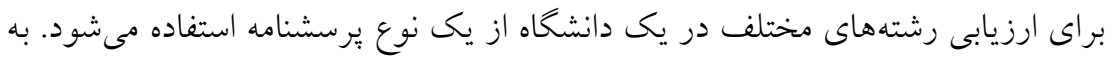

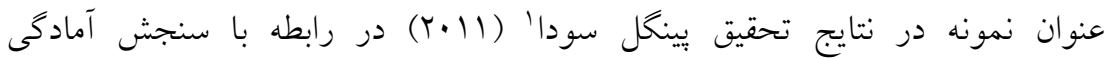

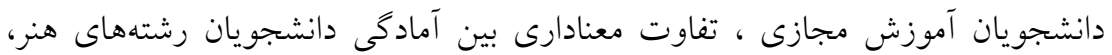

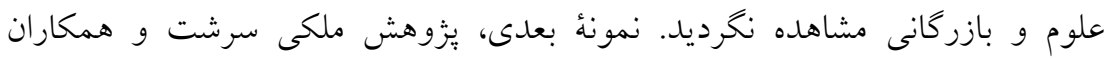

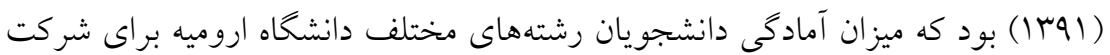
در نظام يادكيرى الكترونيكى را از طريق برسشنامه مشتركى به انجام رساندند.

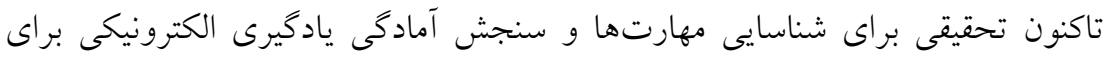

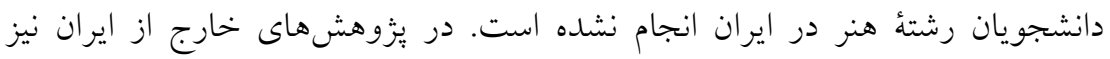

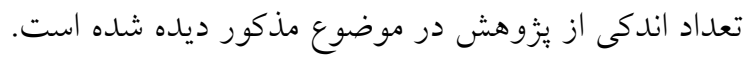

\section{1 .Pingle Sudha}




\section{بيان مسئله و جارجوب نظرى}

فرايند آموزش هنر تحت تأثير عوامل و متغيرهاى متعددى از جمله دانشجو، استاد،

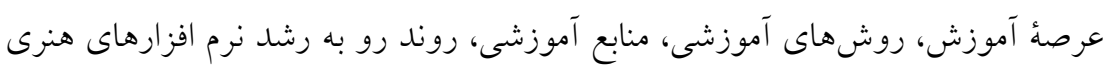
قرار دارد.

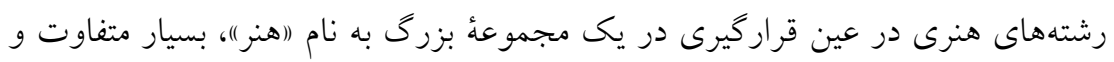

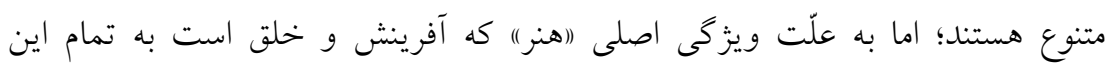
تجلىهاى بيرونى احساس، عنوان هنر و رشتهاى مرتبط با آن را رشتهاى هنى هنرى

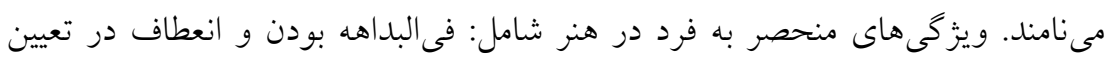

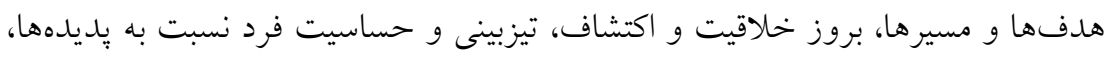

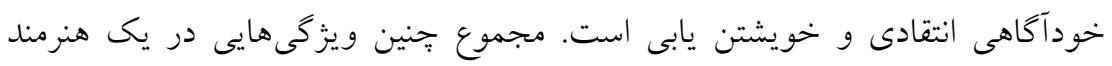

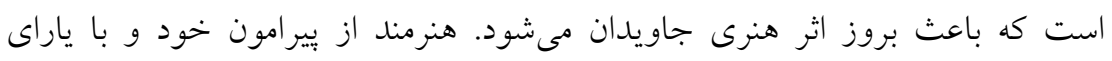

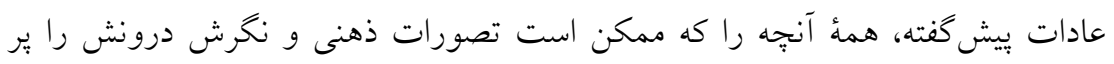

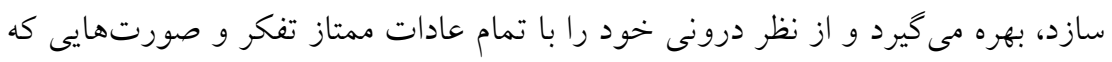

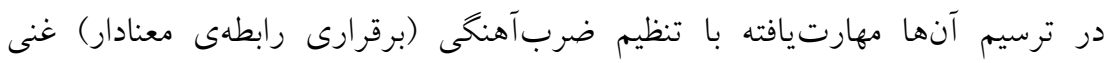

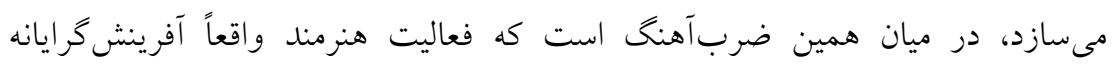
خواهد شد. جون اثر هنرى (حل مسئله) با استفاده از مفاهيم خاصى (فرضيات) توليد شده است (آفرينش)، خود اثر دليلى بر يادگيرى آن مفاهيم است. به طور كلى هنرمندان،

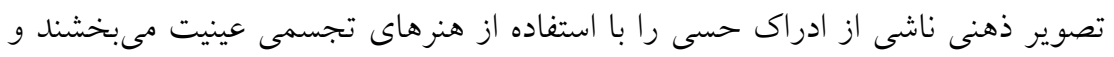

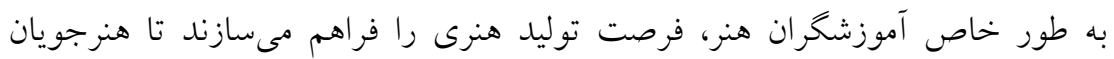

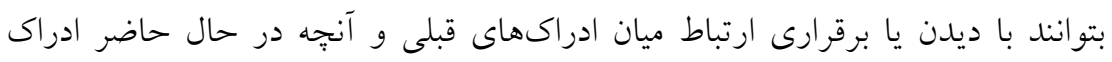

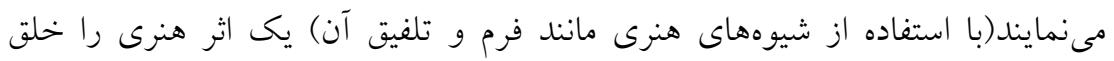
نمايند؛ به عبارت ديخر از طريق بازسازى جهان خارج (تلفيق از برون)، ساختارهاى

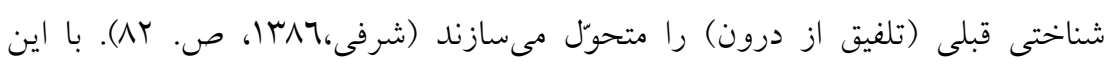

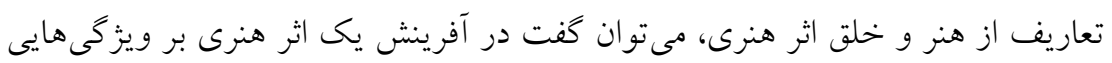


تأكيد مىشود كه عملكردى مشابه با رويكرد سازنده گرايى' دارد. ايده اصلى (اسازنده

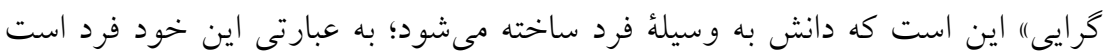

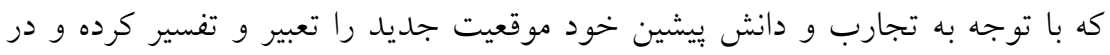

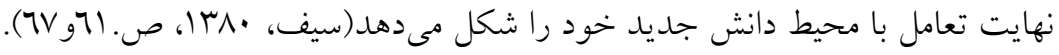

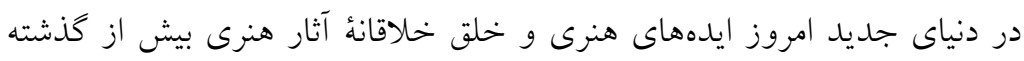

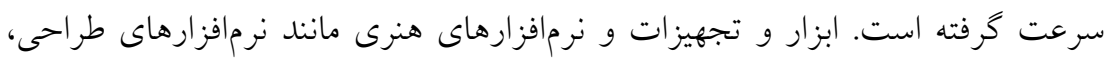

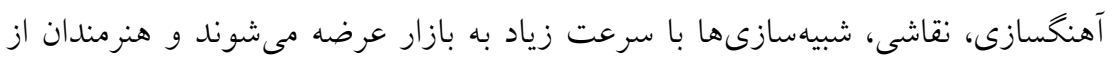

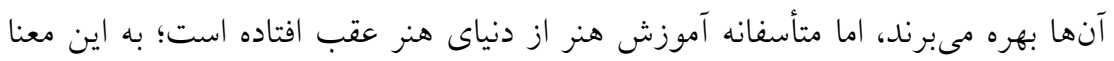

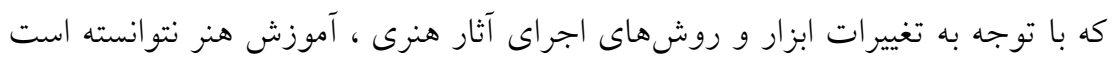

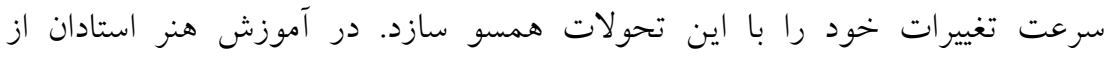

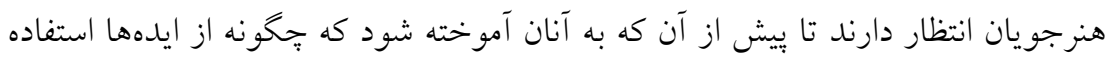

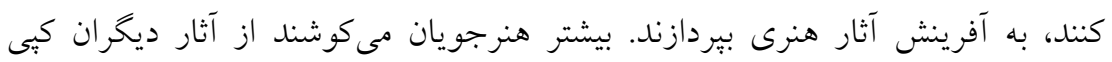

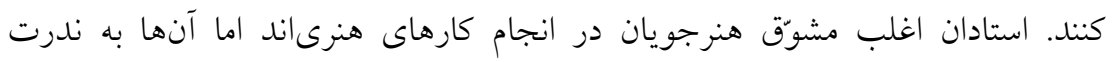

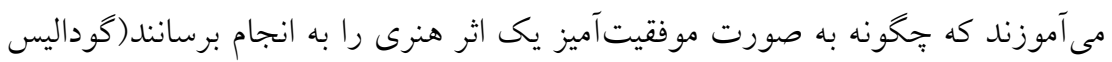

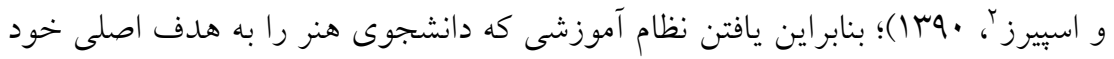

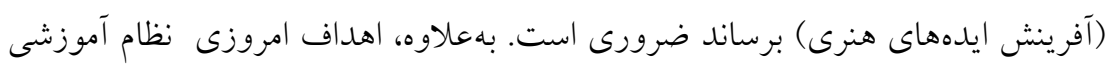

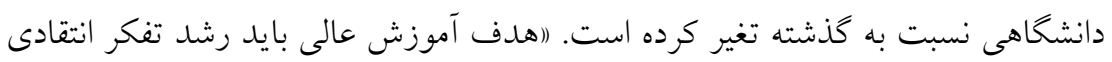

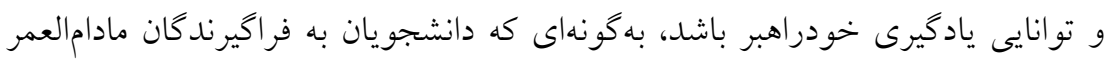

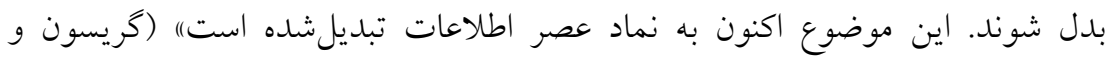

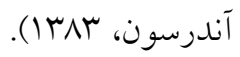
با توجه به نتايج رضايتبخش تحقيقات عملى كه در زمينهُ نظام يادكيرى الكترونيكى در

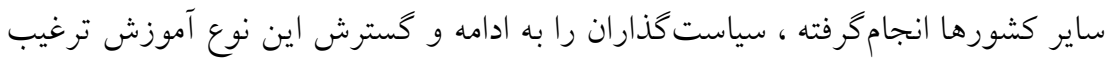


نموده است. ازجملة اين تحقيقات، بزوهشى است با عنوان (يادكيرى مجازى از ديدكاه

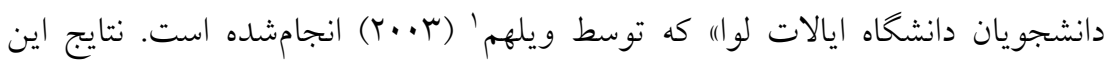

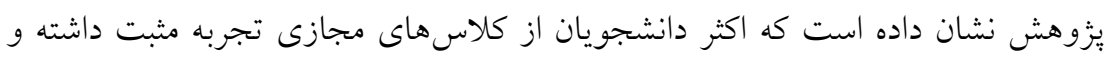

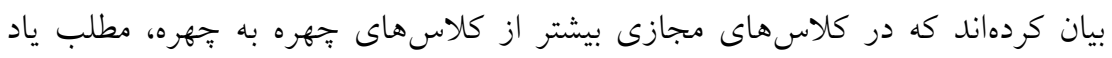

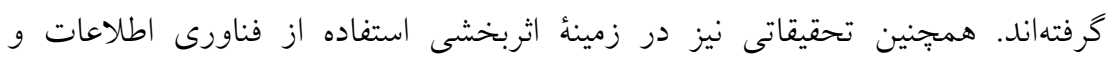

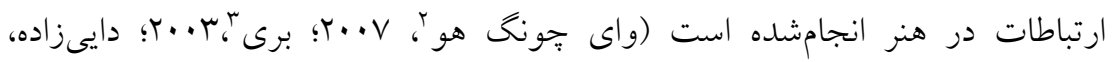

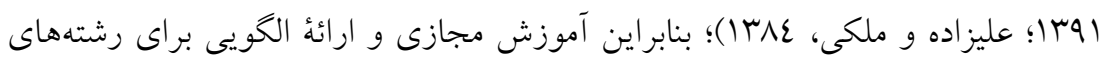

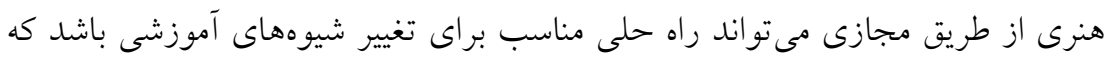

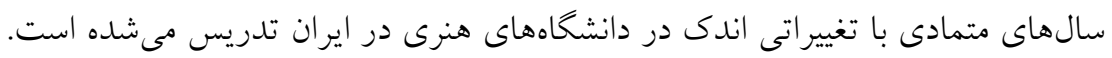

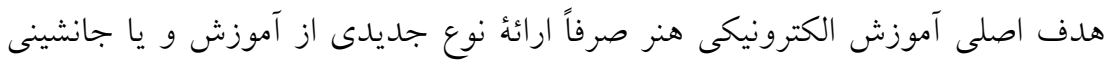

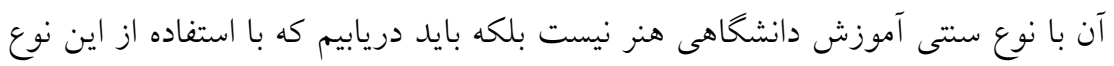

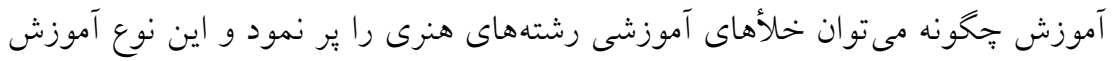

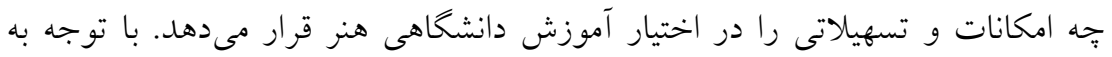

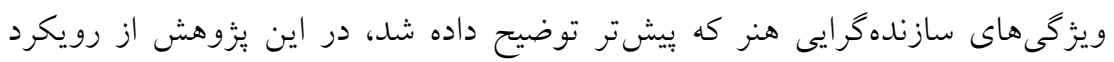

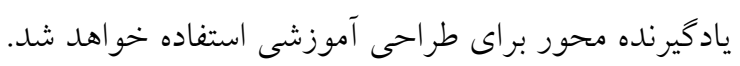

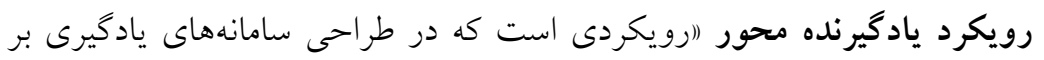

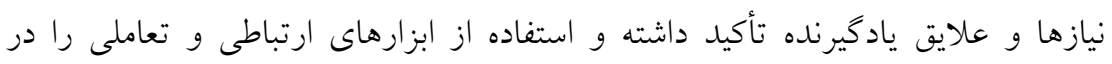

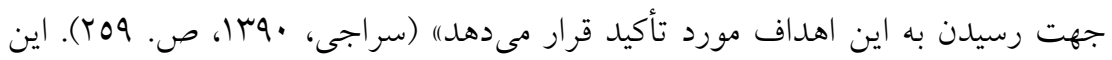

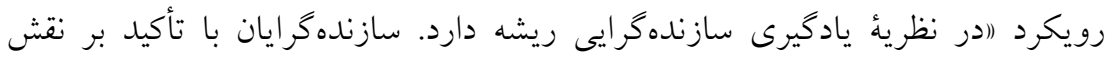

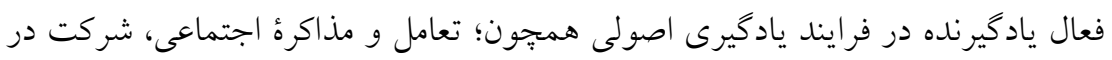
فعاليتهاى يادگيرى اصيل و واقعى، خودرهيابى در يادكيرى، مشاركت و تعامل، ارائه

1. Wilhelm

2. Wai-Chung Ho

3. Nancy H. Barry 
موقعيتهاى مسئلهدار را در ساخت دانش فردى مهم تلقى مىكندا) (جاناسن و

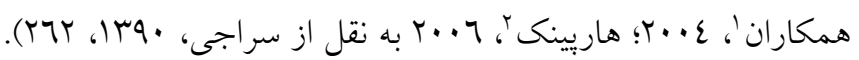

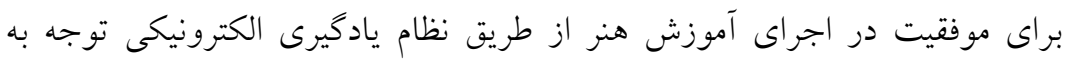

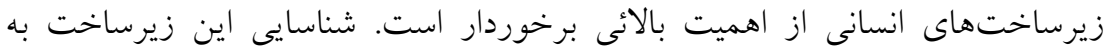

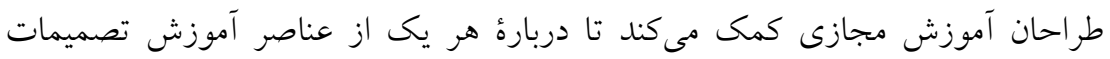
صحيحى اتخاذ نمايند. مسئلة اساسى اين تحقيق اين است كه آيا مهارتهاى دانشجويان در اندازهاى هست

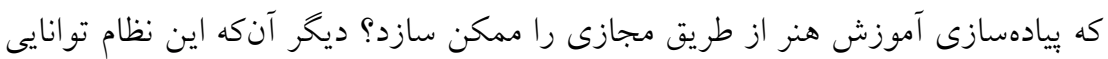

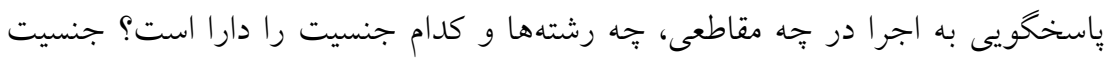

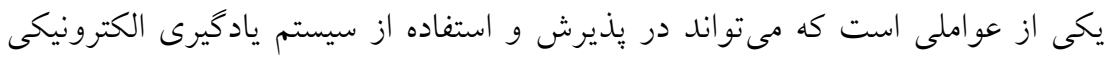

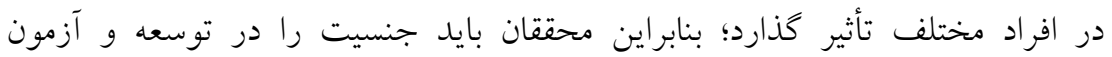

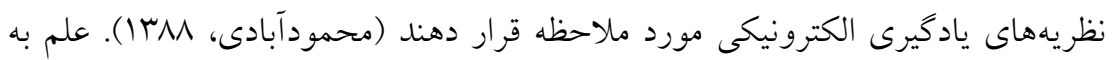

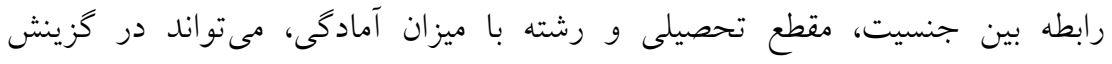
دانشجويان هنر براى شركت در آموزش الكترونيكى و موفقيت بيشتر اين كروهها مؤثر مئر

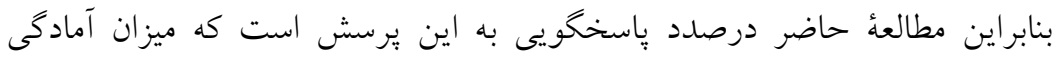

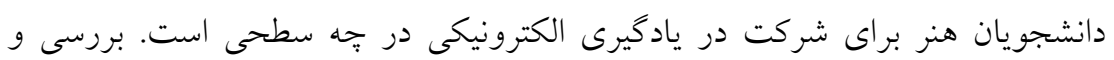

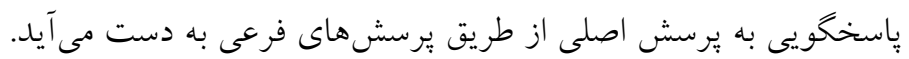
يرسش هاى فرعى مربوطه به شرح زير است:

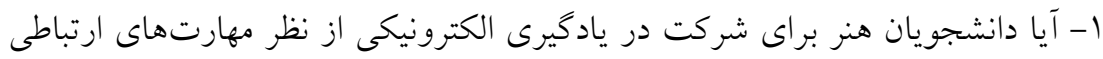

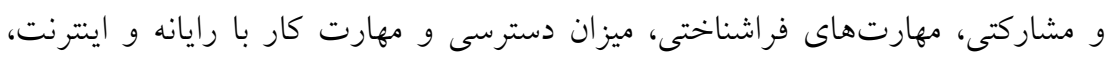

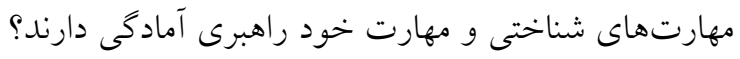

1.D. Johnson., R.Patton., B.Bimber., K. Almeroth \& G. Michaels 2.Dwayne Harapnuik 
ץ-آيا ميزان آمادكى دانشجويان رشتهاى مختلف براى شركت در يادكيرى الكترونيكى

$$
\text { متفاوت است؟ }
$$

ب-آيا ميزان آمادگى دانشجويان هنر براى شركت در يادگيرى الكترونيكى با توجه به

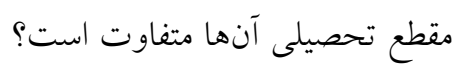

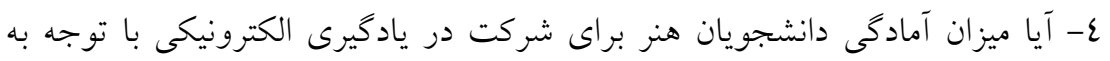

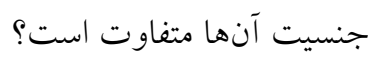

يُزوهش حاضر باهدف بررسى ميزان آمادكى دانشجويان هنر دانشكاههاى الزهرا، تربيت مدرس، دانشخاه هنر و دانشگاه تهران، براى شركت در نظام يادكيرى الكترونيكى طراحى گرديده است.

\section{روش تحقيق}

اين يزوهش از نظر ماهيّت از نوع يزوهشهاى كمّى، از نظر ميزان كنترل متغيرها از نوع غير آزمايشى و از نظر هدف از نوع تحقيقات كاربردى است. از بين دانشخاههاى

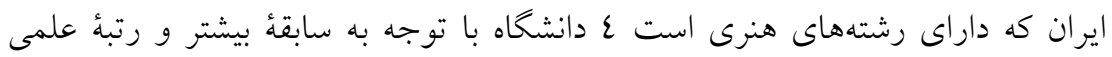

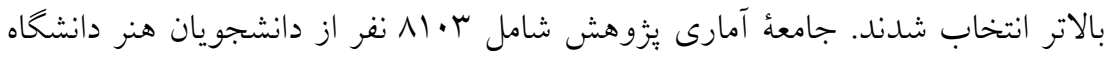

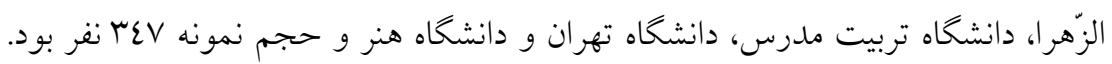

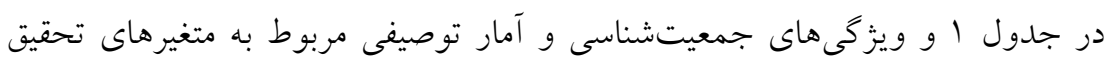

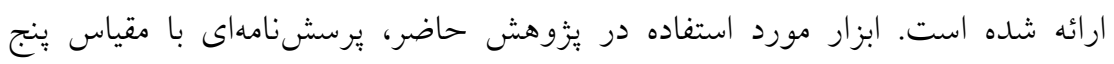

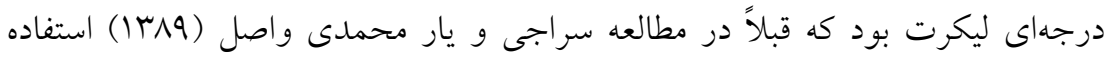

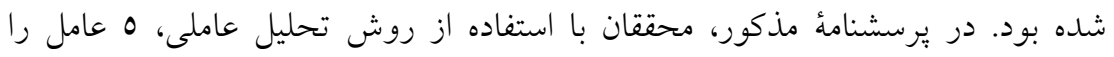

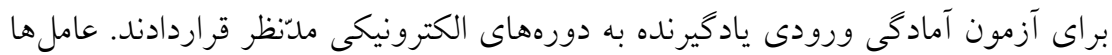

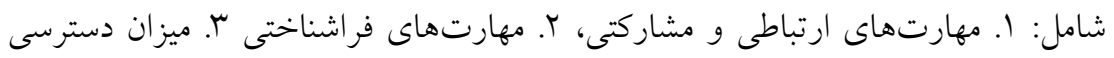
و مهارت كار با رايانه و اينترنت، ع. مهارتهاى شناختى، 0.

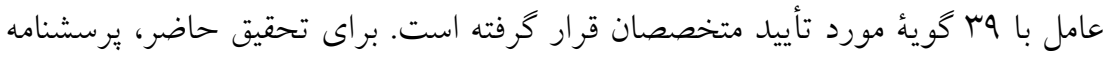

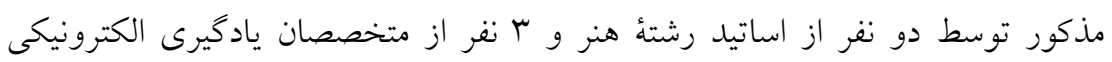


كشور مورد بازبينى قرار كرفت و روايى آن تأييد شد. نتيجه اين كه يرسشنامهاى مشتمل

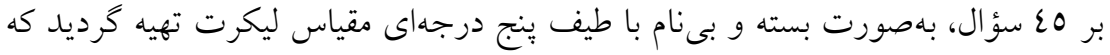

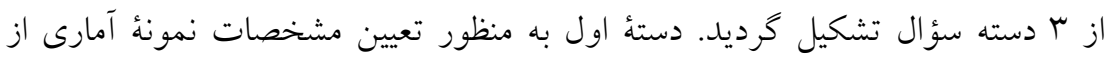
لحاظ جنسيت، مقطع تحصيلى، دانشكدة محل تحصيل و دستهُ دوم شامل سؤالهاى

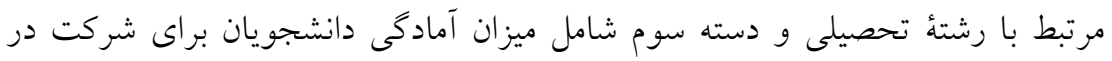

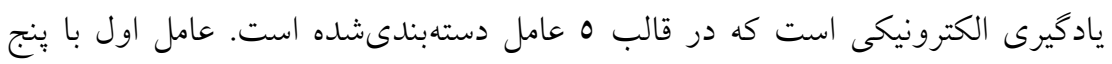

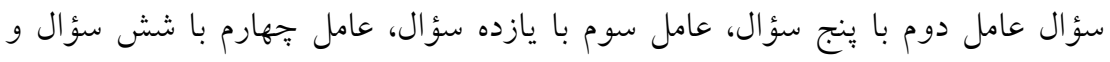

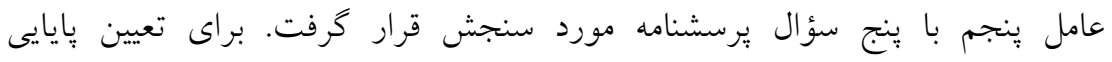

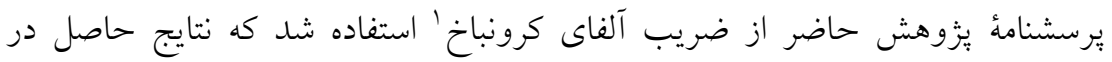

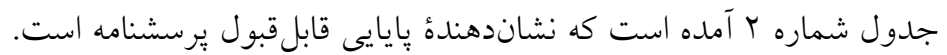

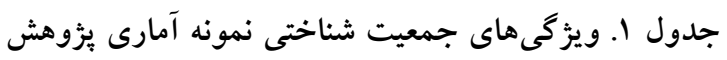

\begin{tabular}{|c|c|c|}
\hline درصد & فراوانى & جنسيت \\
\hline YY/YA & 111 & مرد \\
\hline$T V / V T$ & rro & زن \\
\hline
\end{tabular}

جدول r. آلفاى كرونباخ يرسشنامه ارزيابى آمادگى يادگيرى الكترونيكى در هر يك از عوامل يزوهش عامل عامل عامل عامل عامل عامل

\begin{tabular}{|c|c|c|c|c|c|c|}
\hline كل ابزار & عامج & جهارم & سوم & عامل & عامل & عوامل \\
\hline$\cdot / 17$ & $\cdot / V Y$ & • NY & r/A & $\cdot / 21$ & $\cdot / \Lambda \cdot$ & ضيزائي \\
\hline
\end{tabular}

روش گردآورى اطلاعات بدين صورت بود كه پِ از آن كه تعداد دانشجويان هر

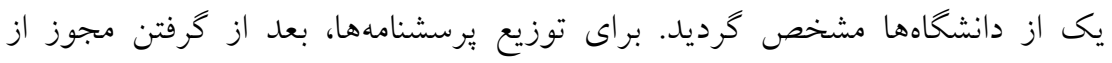

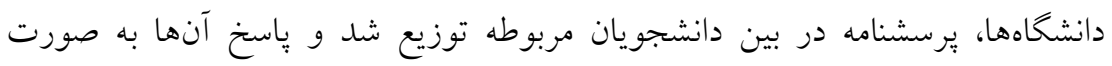

\section{Cronbach alpha}


دادههاى كمّى، مورد استفاده قرار كرفت. يّ از گردآورى دادهها براى تجزيه و تحليل،

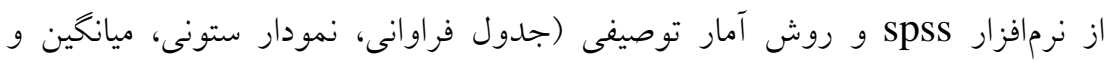

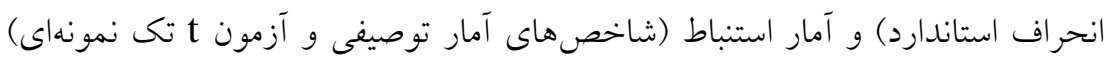

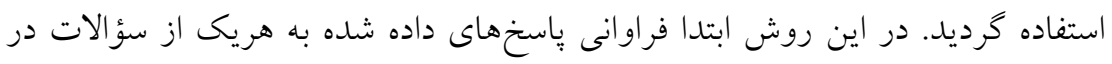

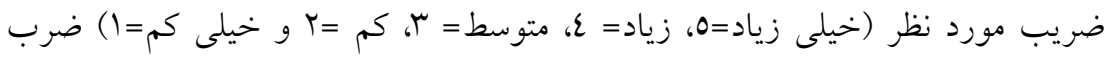

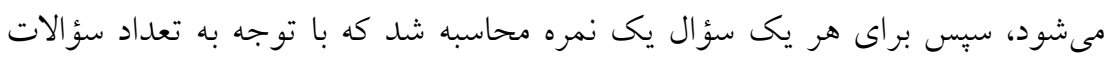

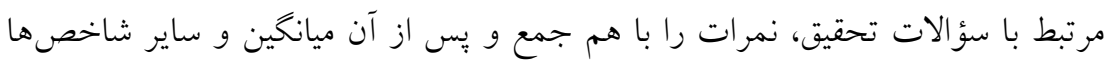

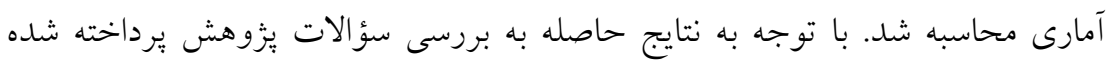

يافته ها:

مشخصات جمعيت شناختى: قسمت اول يرسشنامه شامل سؤالاتى دربارة

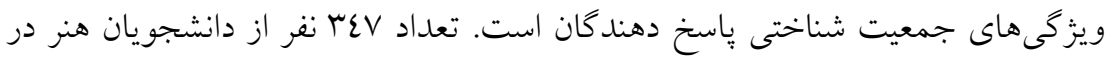

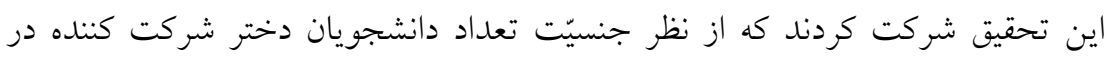

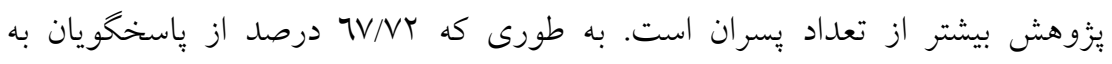

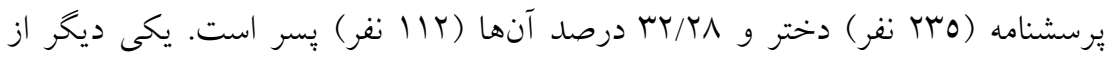

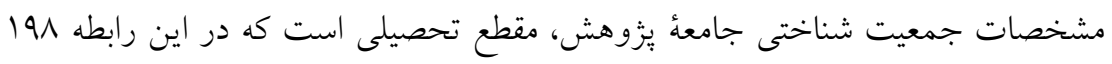

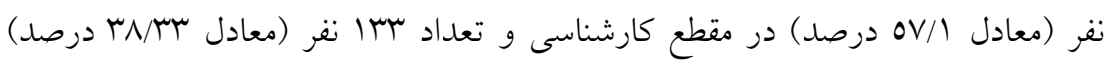
در مقطع كارشناسى ارشد و 17 نفر (معادل الح/ع درصد) در مقطع دكترى مشغول به تحصيل بودهاند.

سؤال اول. آيا دانشجويان هنر براى شركت در يادكيرى الكترونيكى از نظر مهارتهاى ارتباطى و مشاركتى، مهارتهاى فراشناختى، ميزان دسترسى و مهارت

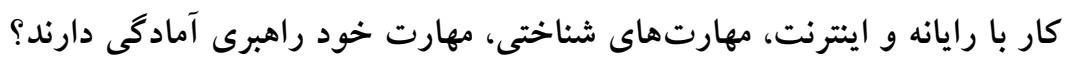




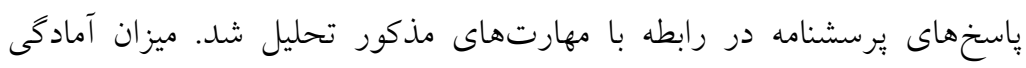

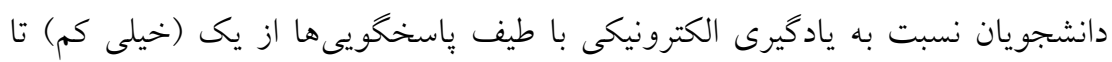

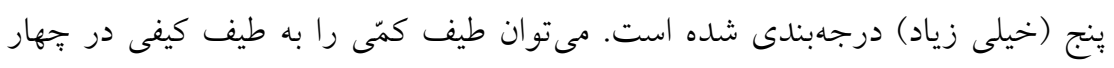

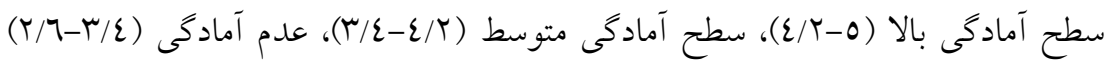

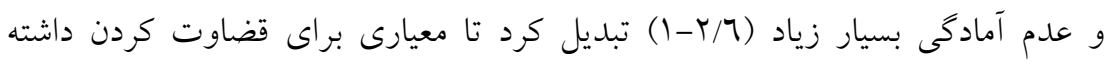
باشيم.

با توجه به نمرات در نظر كرفته شده (1 تا ه) براى اندازهكيرى، مرز بين آمادكى

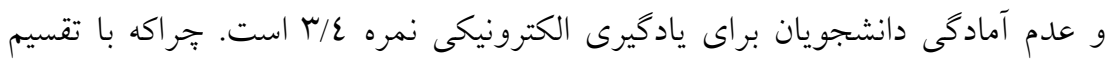

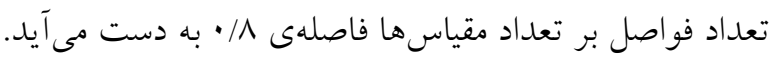

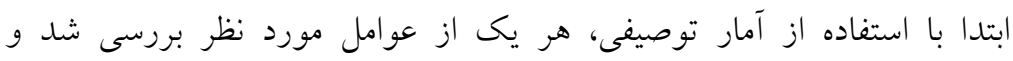

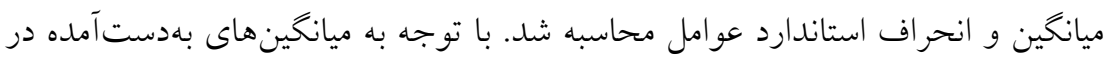

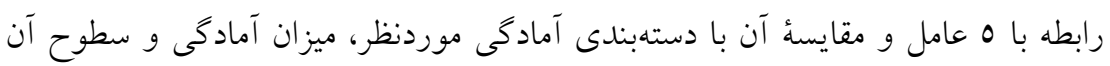
مشخص مى گردد. نخستين عامل مهارتهاى ارتباطى و مشاركتى مورد نياز براى يادگيرى

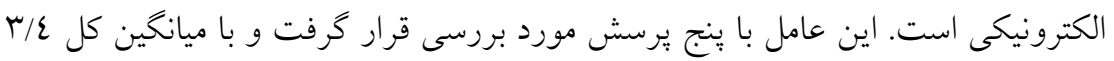

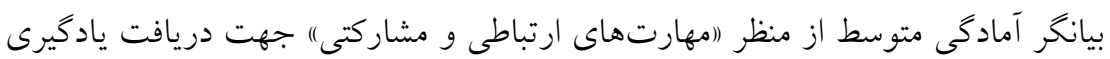
الكترونيكى در دانشجويان است.

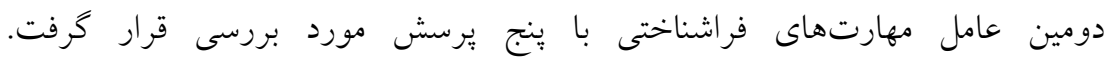

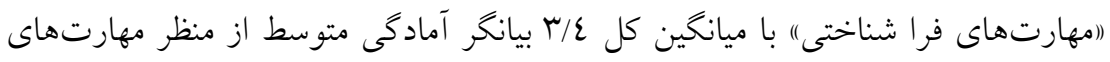
فراشناختى جهت دريافت يادگيرى الكترونيكى در دانشجويان است.

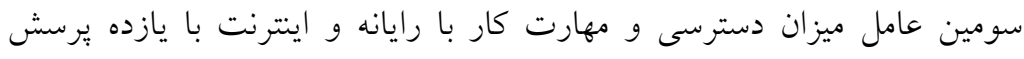

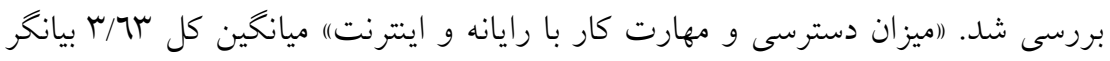

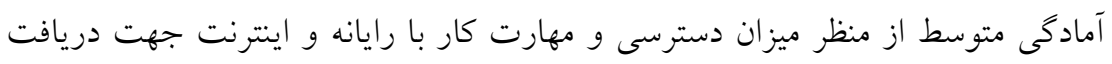
يادگيرى الكترونيكى در دانشجويان است. 
جهارمين عامل مهارتهاى شناختى با شش يرسش مورد بررسى قرار كرفت.

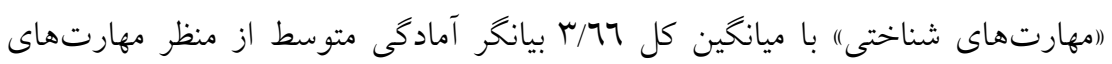
شناختى جهت دريافت يادگيرى الكترونيكى در دانشجويان است.

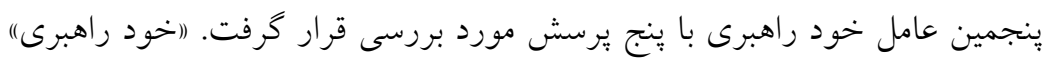

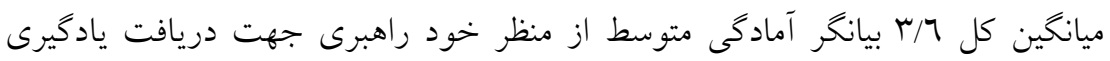
الكترونيكى در دانشجويان است. با توجه به دادههاى توصيفى و هم:جنين با عنايت به دستهبندى دآمادكى يادئ ياديرى

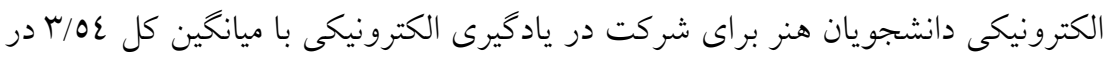
سطح آمادكى متوسط قرار دارد.

سؤال دوم - آيا ميزان آمادگى دانشجويان رشتههاى مختلف براى شركت در يادگيرى الكترونيكى متفاوت است؟

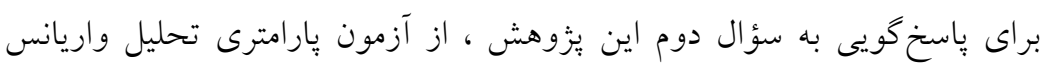

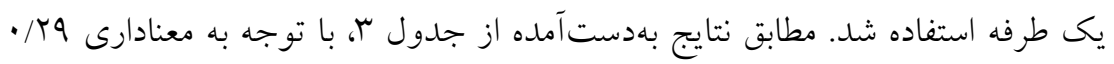

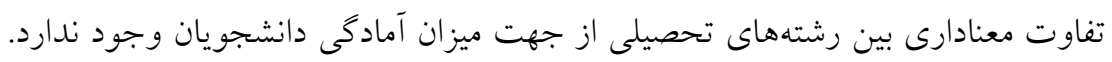

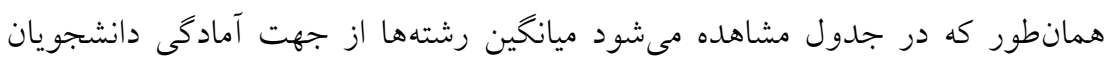

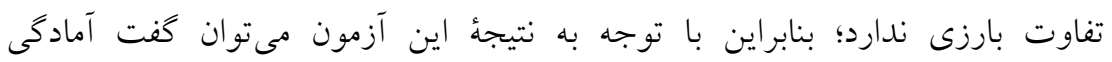

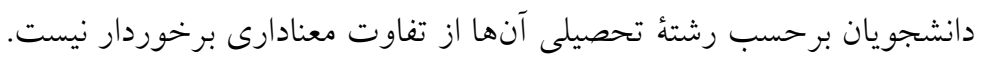


دو فصلنامة نظريه و عمل در برنامئ درسى، شمارة 0، سال سوم، بهار و تابستان ع9r|

جدول r. نتايج آزمون تحليل واريانس يكىطرفه براى بررسى تفاوت ميانكينها بين آمادگى دانشجويان به تفكيك رشتئ تحصيلى

\begin{tabular}{|c|c|c|c|}
\hline سطح معنادارى & مقدار آزمون & ميانكين & | رشته \\
\hline \multirow{17}{*}{$\cdot / r q$} & \multirow{17}{*}{$1 / 17$} & $1 \cdot r / 0$. & \\
\hline & & $1 \cdot r / 7$. & ى يار ¥جه و لباس \\
\hline & & $1 \cdot 0 / 7 Y$ & \\
\hline & & $1 \cdot 1 / 1 \cdot$ & \\
\hline & & $1 \cdot 9 / \varepsilon \cdot$ & \\
\hline & & $1 \cdot 9 / 77$ & ي صحنه \\
\hline & & $11 \cdot \% \cdot V$ & \\
\hline & & $\mid 1 \cdot / \varepsilon 1$ & ى نمايشى و سينما \\
\hline & & س & لهازى \\
\hline & & $11 \pi / 0$. & متحرى \\
\hline & & $11 \pi / 0$. & ل ل لامى \\
\hline & & $11 \% / 7 Y$ & ات تصويرى \\
\hline & & $11 \varepsilon / \cdot 9$ & بعدستى \\
\hline & & $117 / r$ & رى و شهرسازى \\
\hline & & $117 / 47$ & احى صنعتى \\
\hline & & $11 \mathrm{~V} / \ldots$ & لى هنر \\
\hline & & $119 / \cdot 0$ & \\
\hline
\end{tabular}

سؤال سوم- آيا ميزان آمادكى دانشجويان هنر براى شركت در يادگيرى الكترونيكى

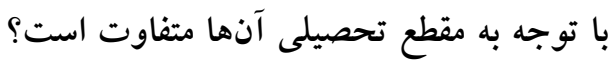


جدول ع. نتايج آزمون تحليل واريانس يكى طرفه براى بررسى تفاوت ميانحينها بين آمادگى دانشجويان به تفكيك مقطع تحصيلى

\begin{tabular}{|c|c|c|c|}
\hline سططح معنادارى & مقدار آزمون & ميانكين & مقطع \\
\hline.$/ \cdot 1$ & $0 / 19$ & $111 / \varepsilon 9$ & كارشناسى \\
\hline & & $11 \% / 04$ & رشناسى ارشد \\
\hline & & $1 r 0 / 9 \varepsilon$ & رى \\
\hline
\end{tabular}

براى آزمون فرضية بالا، از آزمون بارامترى تحليل واريانس يكسطرفه و آزمون

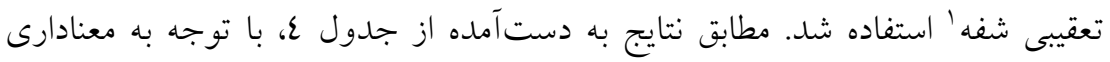

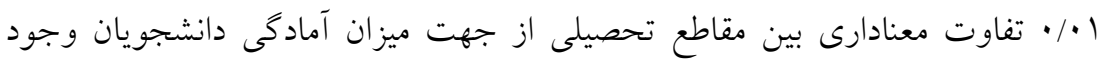

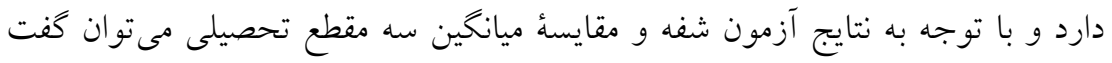

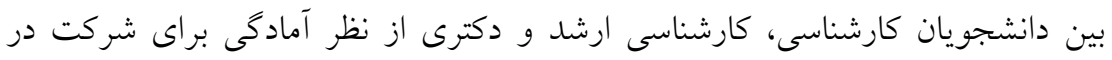

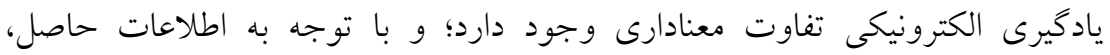

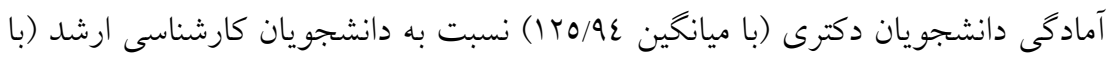

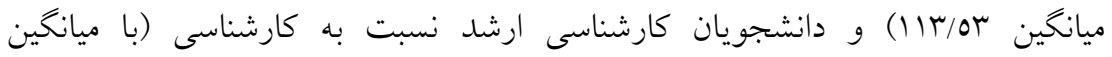
9اع/111/29) بالاتر است.

سؤال جهارم- آيا ميزان آمادگى دانشجويان هنر براى شركت در يادگيرى

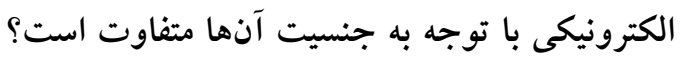

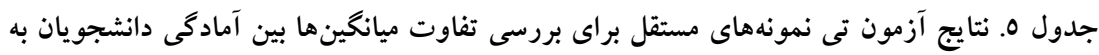

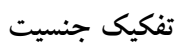

\begin{tabular}{|c|c|c|c|}
\hline مطح معنادارى & مقدار آزمون & ميانگين & لجنس \\
\hline \multirow{2}{*}{$\cdot T \wedge N$} & & $\| K / T N$ & ن \\
\hline & & $\| \varepsilon / \mu \mid$ & \\
\hline
\end{tabular}

1.Scheffe 
براى آزمون فرضية بالا، از آزمون بِارامترى تى نمونههاى مستقل استفاده شد. مطابق

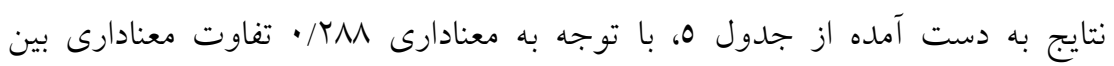

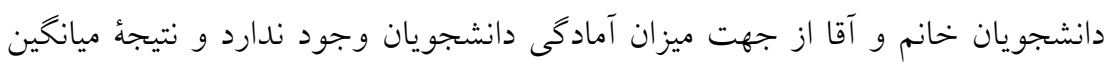

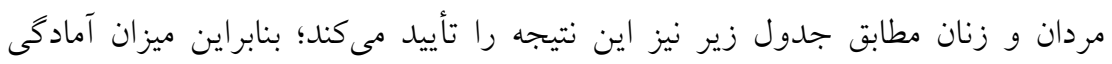
برحسب مرد يا زن بودن دانشجو از تفاوت معنادارى برخوردار نيست.

\section{بحث و نتيجه گيرى}

يزوهشهايى كه در زمينه بررسى علل افت دورههاى يادگيرى الكترونيكى

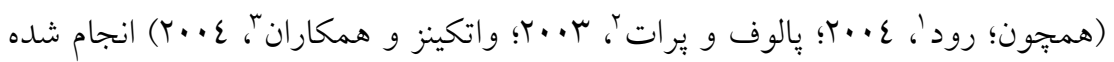

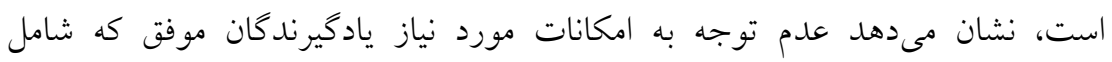

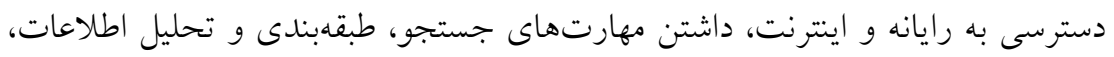

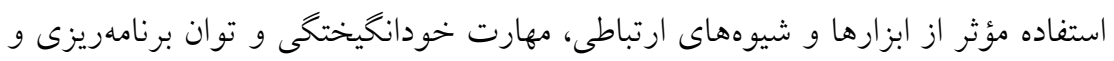

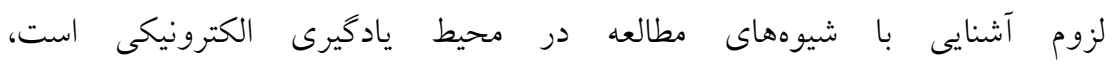

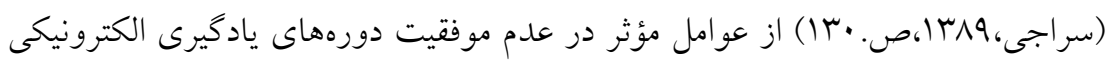

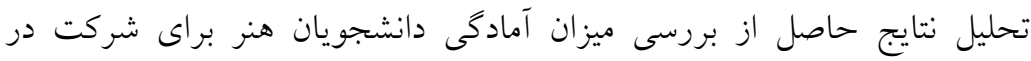

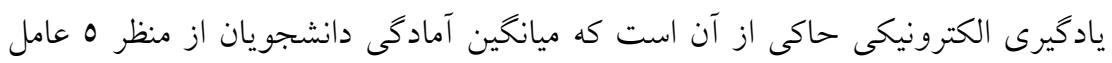

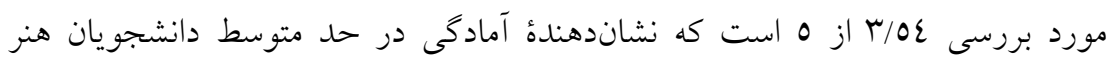
براى شركت در يادكيرى الكترونيكى است. در اين بخش تلاش مىشود جزئيات

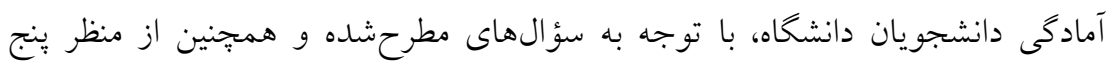
عامل مختلف مورد بررسى قرار كيرد.

1. Rhode

2.Pratt \& Pallof

3. Ryan Watkins; Doug Leigh; Don Triner 


\section{عامل اول- مهارتهاى ارتباطى و مشاركتى}

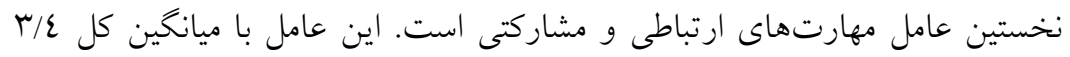

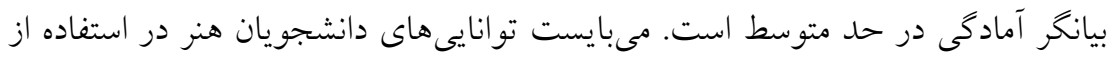

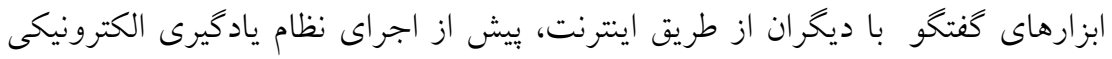

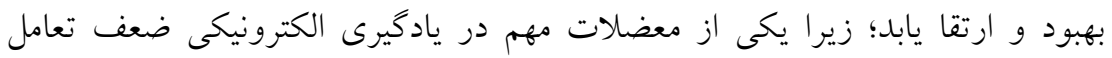

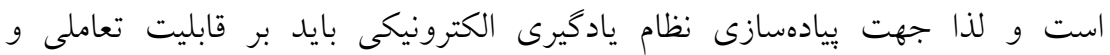

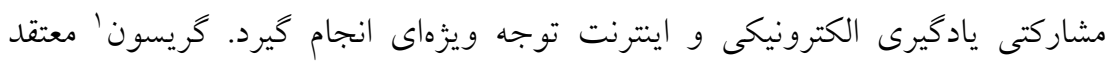

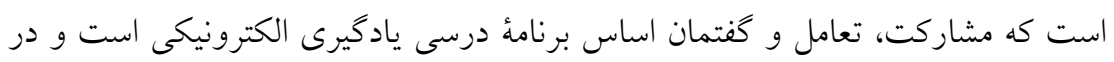

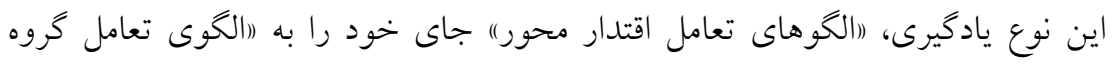

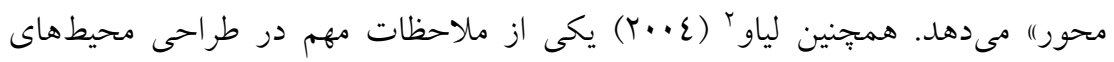

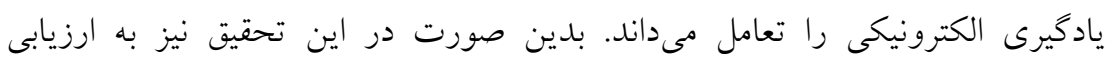

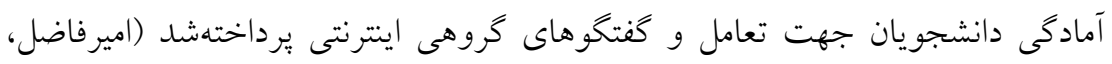

. (TY ITM

\section{عامل دوم - مهارتهاى فرا شناختى}

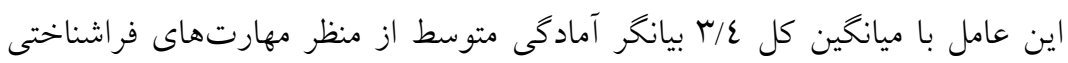
در دانشجويان هنر است.

يكى از نكات اساسى در آموزش (به ويزه آموزش مجازى) اين است كه فراكيران

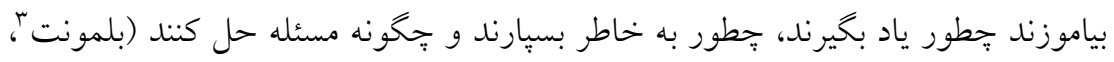

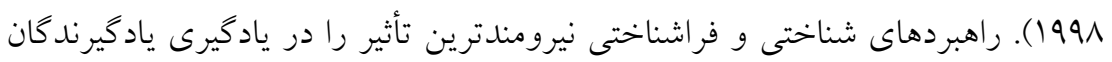

1. Garrison D.R.

2. Liaw

3. Belmont 
دارند و رابطؤ مثبت و معنادار بين شيوه يادگيرى و بيشرفت تحصيلى در دانشخاه وجود

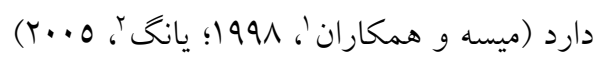

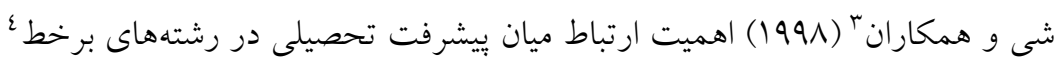

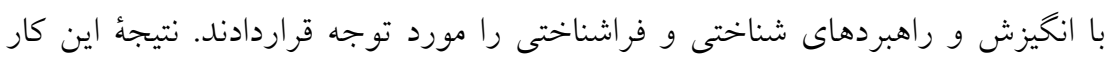

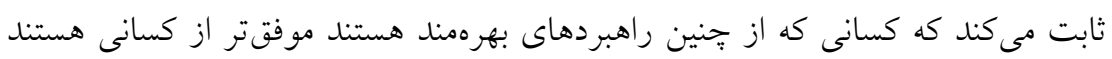
كه اين راهبردها را كمتر به كار مىبرند.

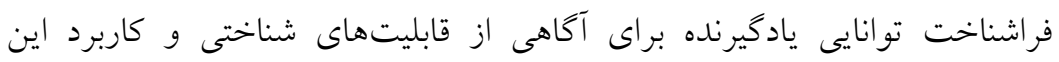

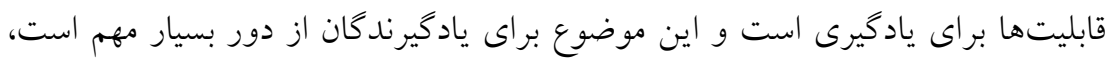

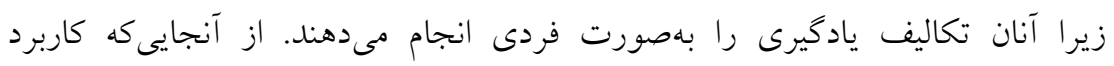

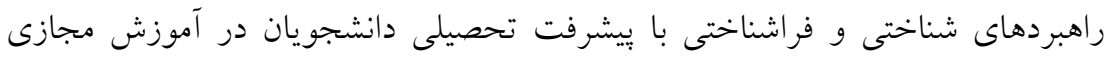

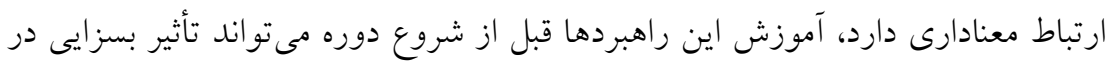
بهبود عملكرد دانشجويان داشته باشد.

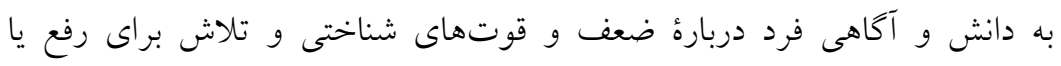

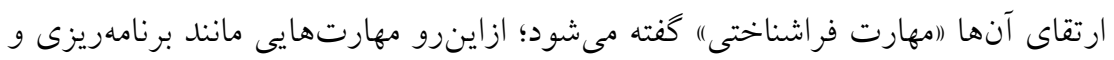

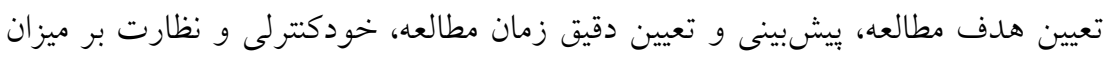

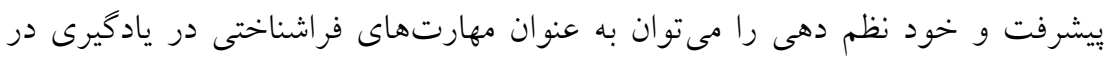
نظر كرفت.

\section{عامل سوم - ميزان دسترسى و مهارت كار با رايانه و اينترنت}

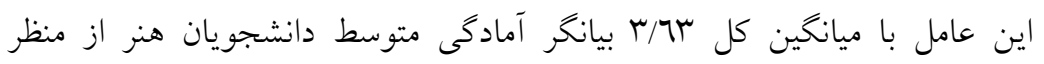

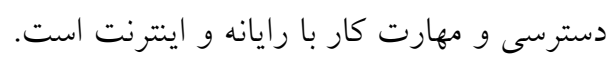

1. Meece et al.

2. Yang

3. Shih et al.

4. Online Courses 
"ادر محيط يادگيرى مجازى دانشجو براى دسترسى به محتواى آموزشى، انجام

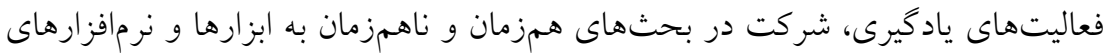

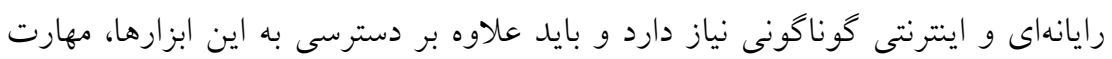

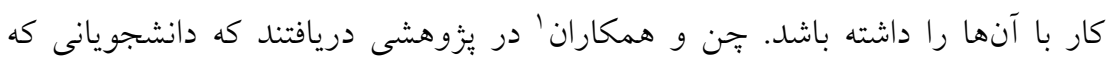

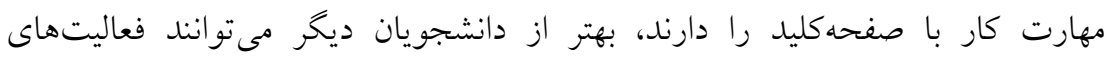

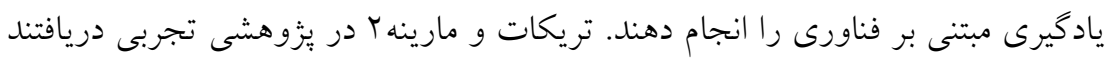

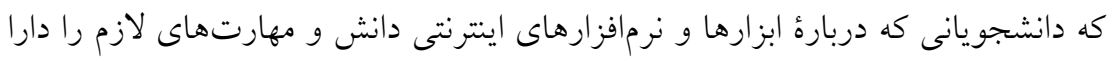

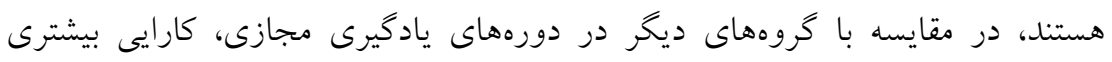

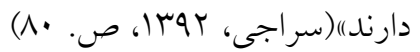

\section{عامل جهارم- مهارتهاى شناختى}

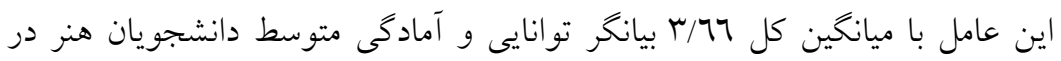
رابطه با مهارتهاى شناختى است.

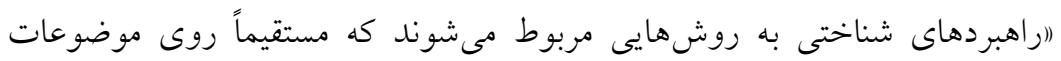

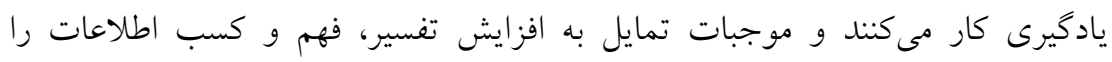

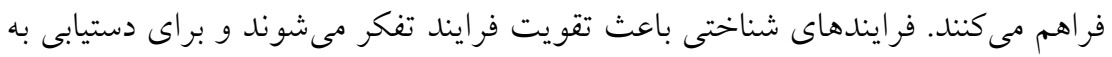

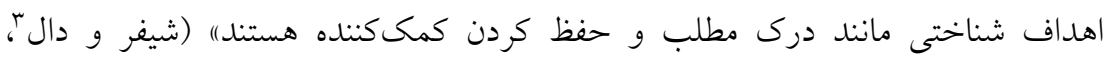

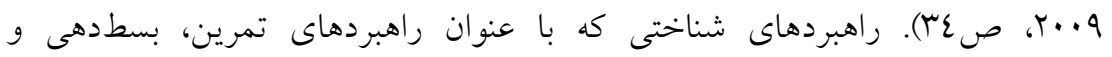

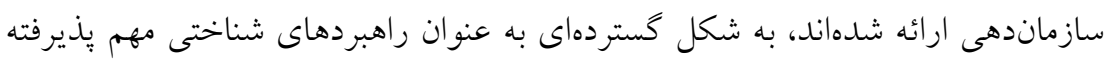

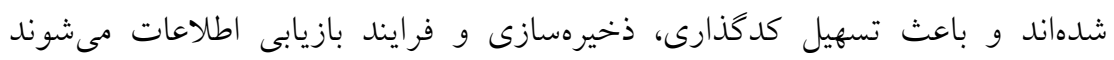

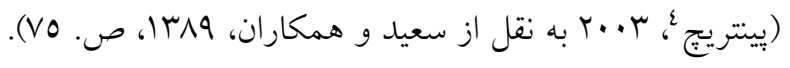

1. Chan. L. M. Y, Jones. A.C, Eileen. S, Richard.J

2. Babin. L. M, Tricot. M \& Mariné. C.

3. Shleifer and Dull

4. Pintrich 
"ادر محيط يادگيرى الكترونيكى، يادگيرنده به منابع اطلاعاتى گوناكون دسترسى

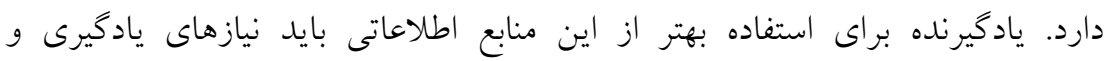

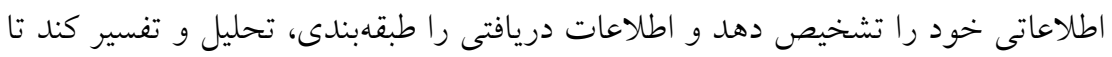

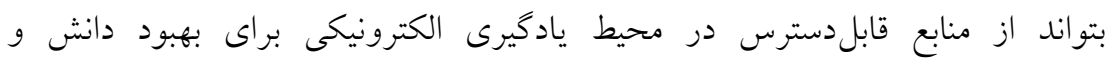

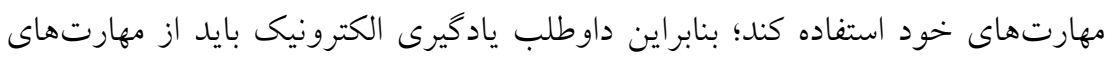

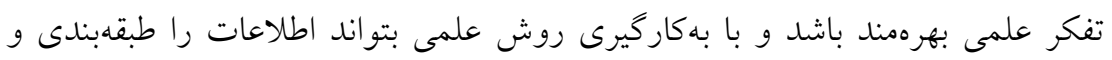

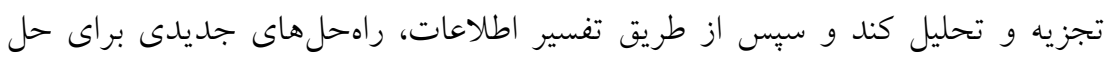

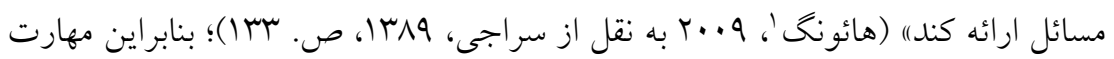

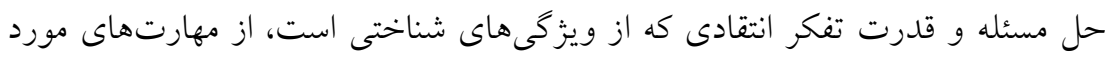

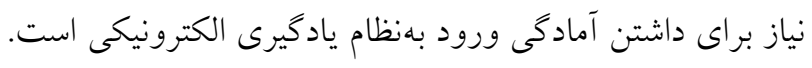

\section{عامل ينجم - خود راهبرى}

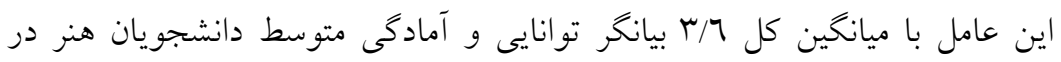

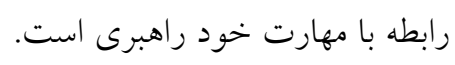

به مجموعة مهارت هايى كه فرد با استفاده از آن، نيازهاى يادكيرى خود ردي را تشخيص

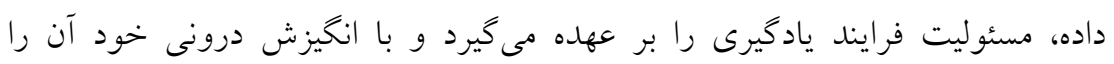

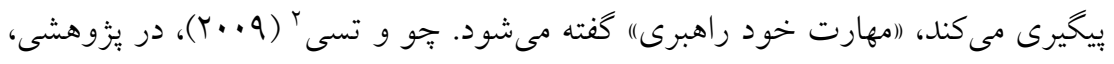

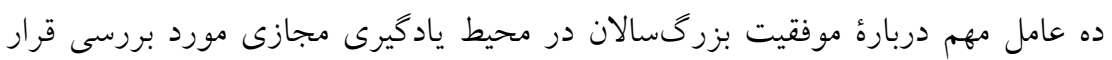

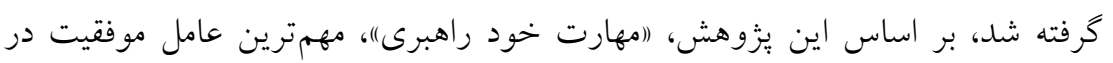

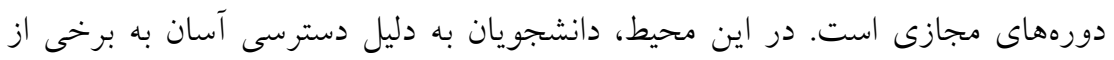

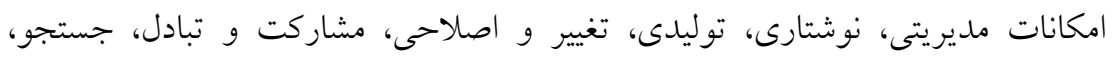

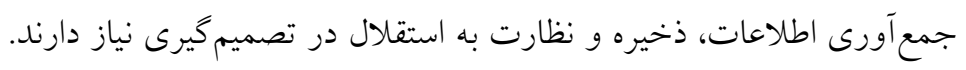

1. Huang

2. Chu. R.J.C \& Tsai. 
به دليل خودآموز بودن محيط يادگيرى الكترونيكى و امكان دسترسى به منابع

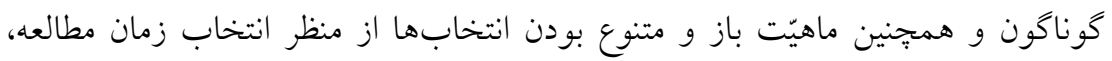

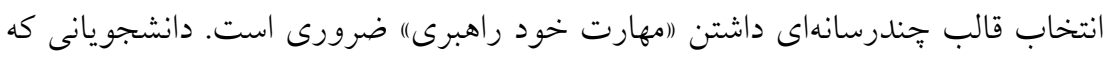

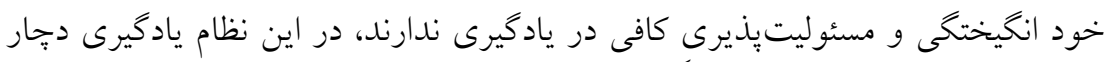

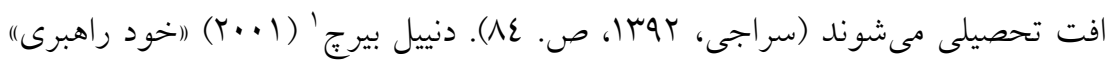
را يكى از ويزگى هاى يادگيرندكان موفق مى مداند.

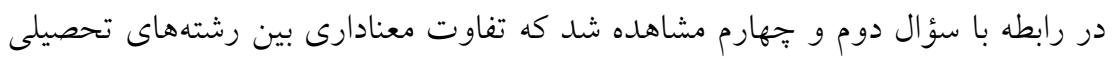

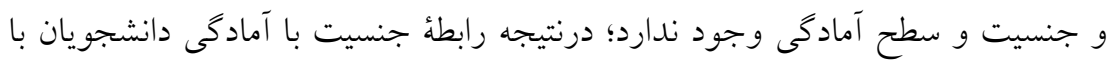

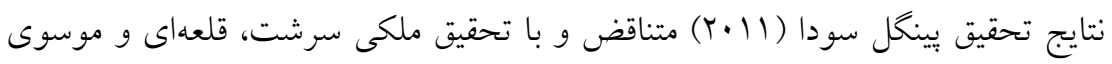

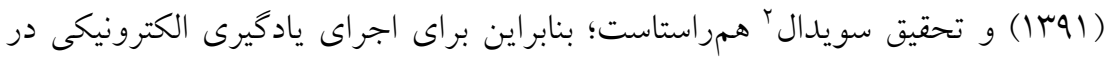
رشتهاى مختلف هنرى از نظر دانشجويان مىتوان طرح هماهنكى را استفاده كرد. در رابطه با سؤال سوم مشاهده شد كه آمادكى دانشجويان مقطع دكترى از ديخر دانشجويان

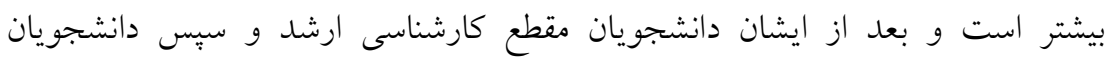

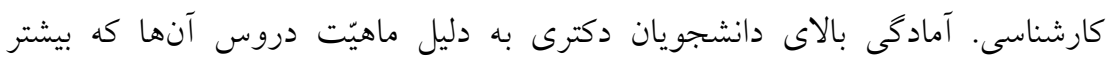
تحقيقى بوده و نيازمند استفاده از روشهاى علمى دهى بيشتر است همجنِين استفاده بيشتر

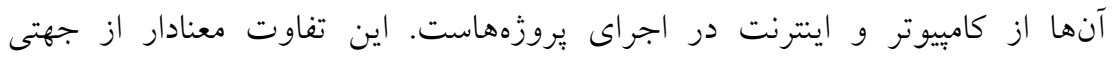

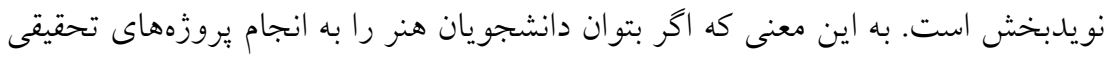

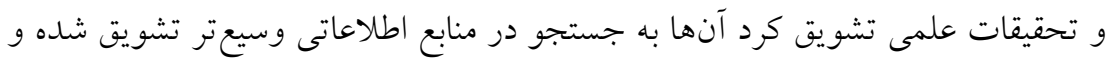
مهارتهاى مورد نياز براى شركت در يادكيرى الكترونيكى در آنها ارتقا مى ميابد. عدم تفاوت معنادار بين رشتهاى تحصيلى دانشكدههاى هنر نشان از يكنواختى و و

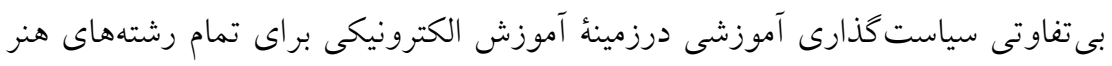

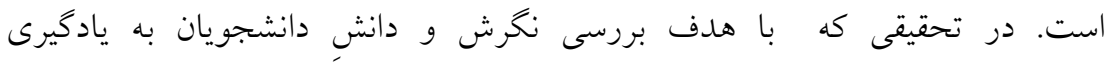

1. Birch, D

2. Soydal 
الكترونيكى در دانشكاه علوم يزشكى مشهد انجام گرفت، نتيجه مشابهى در رابطه با عدم

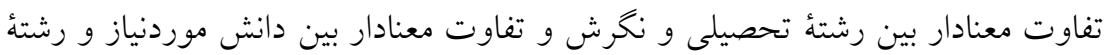

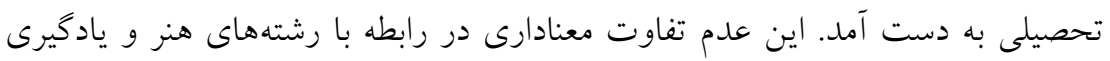

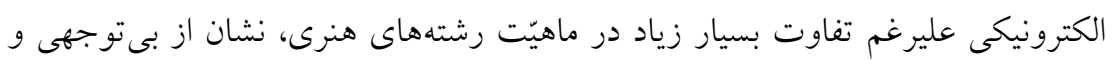

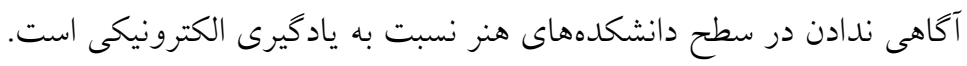

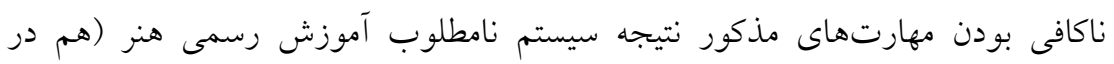

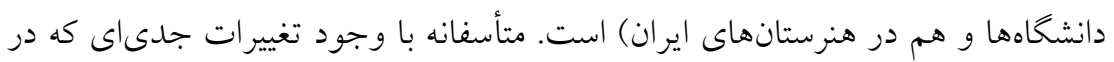

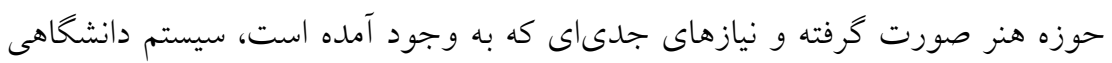

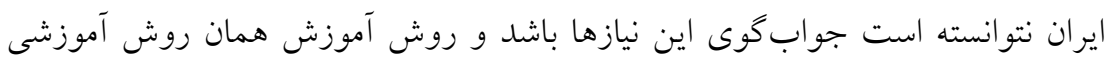

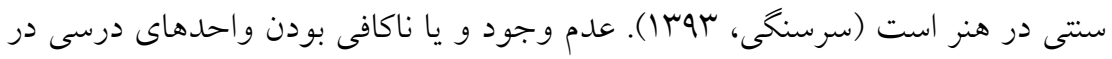

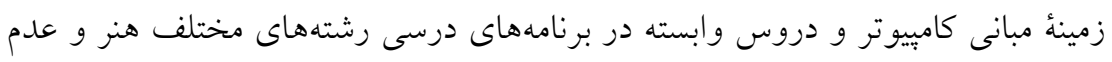

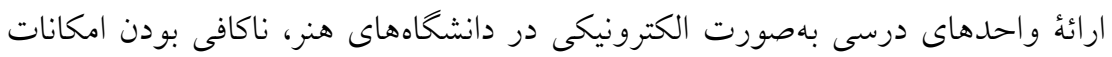
استفاده از رايانه و اينترنت توسط دانشجويان و مهمتر از همه بهورت عدم آشنايى اساتيد

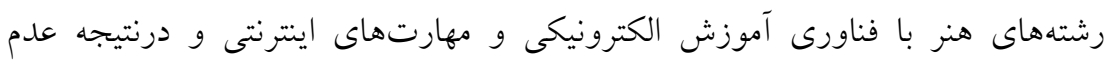

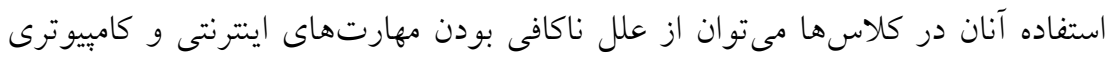
باشد.

\section{بيشنهادها}

همانطورى كه يافتهاى تحقيق حاضر نشان مىدهد، دانشجويان هنر براى شركت در

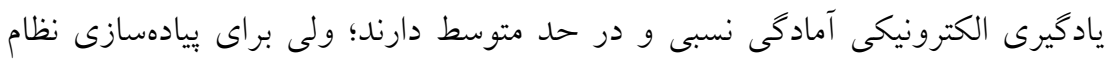

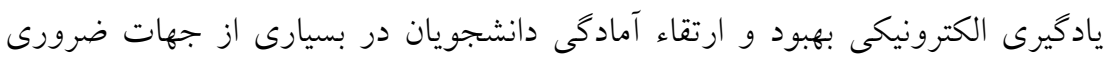

يكى از راهكارهاى مناسب براى موفقيت اجراى اين نظام، آشنا كردن دانشجويان با

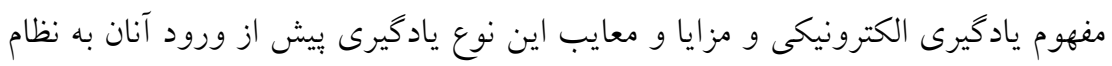


يادگيرى الكترونيكى است. بسيارى از دانشجويانى كه به عرصهُ يادگيرى الكترونيكى

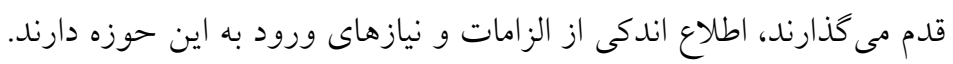

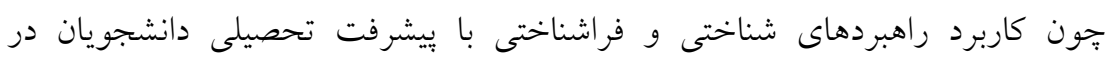

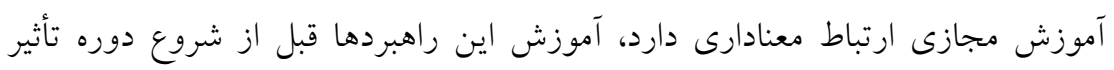

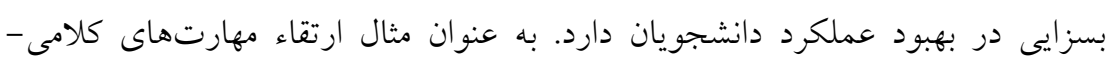
نوشتارى. افزايش يادگيرى هميارانه و ارائه تكاليف گروهى به منظور افزايش يادگيرى مشاركتى راهكار ديخر افزايش مهارت تعامل دانشجويان است.

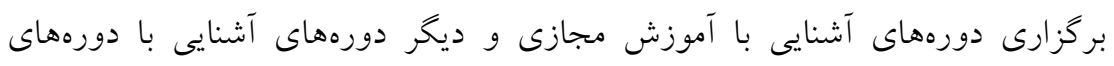

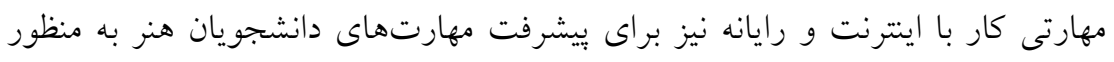
شركت در دورههاى ياد گيرى الكترونيكى الزامى است.

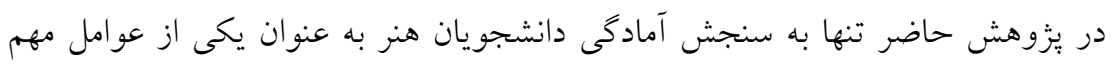

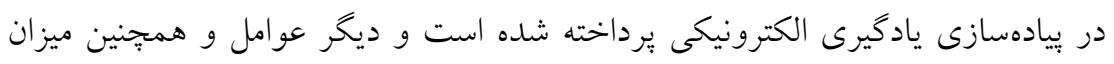

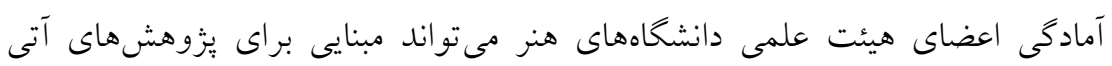

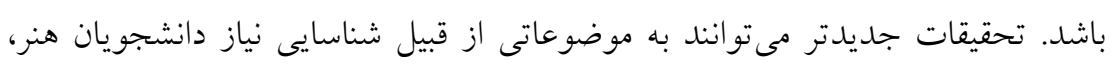

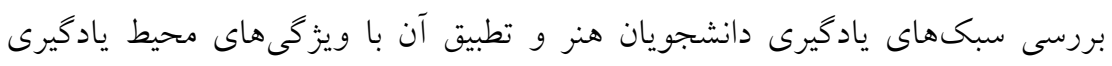

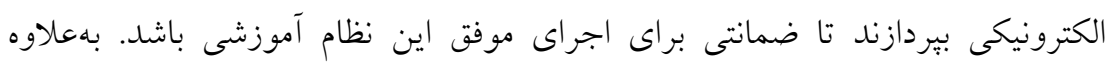

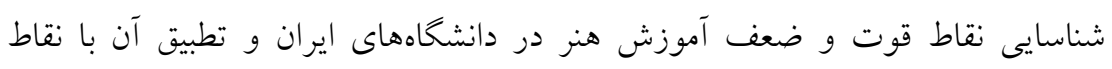

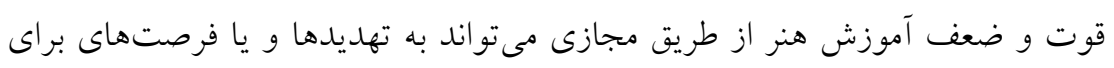

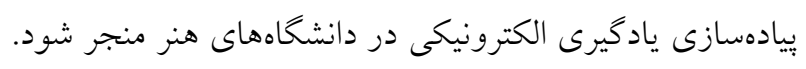




\section{منابع}

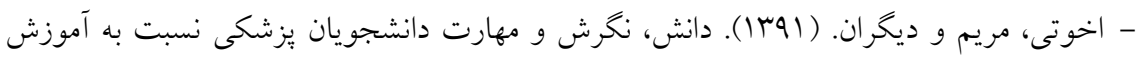

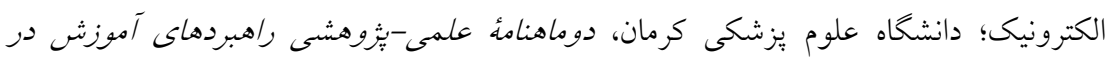

$$
\text { علوم بزشكىى، 1، 01-01. }
$$

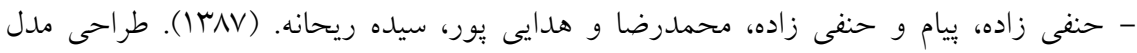

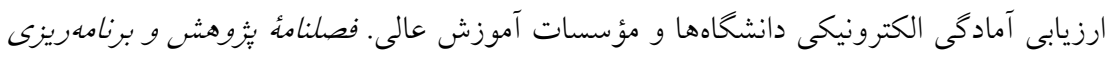

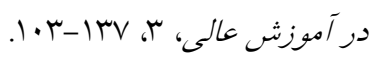

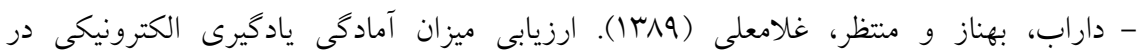

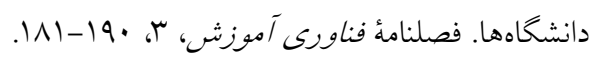

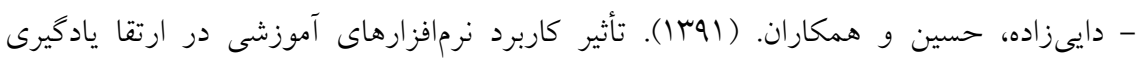

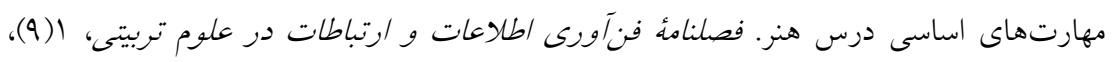

$$
. r V-\varepsilon r
$$

- رحيمى دوست، غلامحسين و رضوى، سيد عباس. (19 إ). امكانسنجى اجراى يروزه يادكيرى

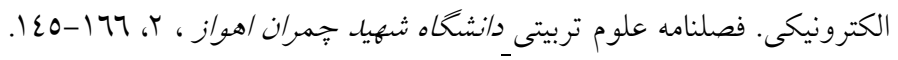

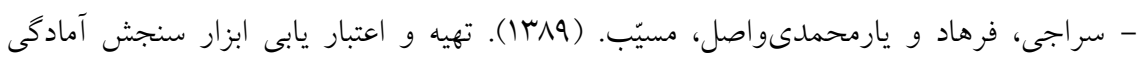

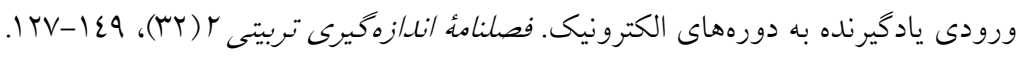

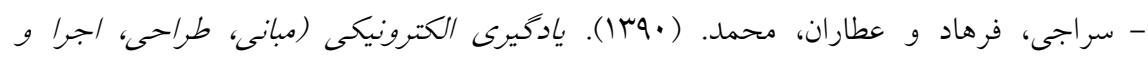
ارزشيابى). همدان: انتشارات دانشگاه بوعلى سينا.

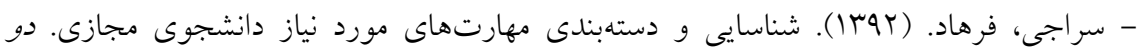

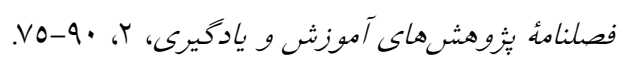

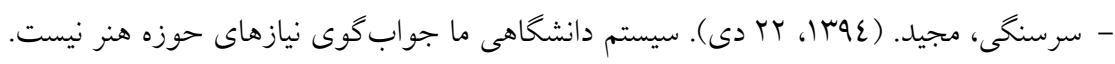

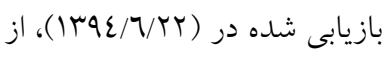

http://www.iranartists.org/Fa/News/News.aspx?nwsId=2937 - سعيد، نسيم و همكاران. (1/199). ارتباط راهبردهاى شناختى، فراشناختى و تعاملات دانشجويان

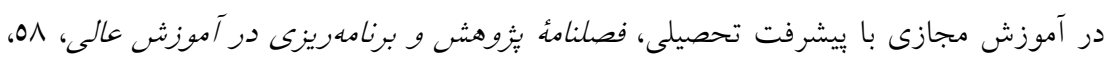




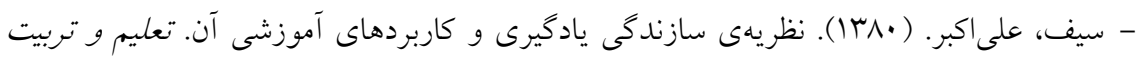

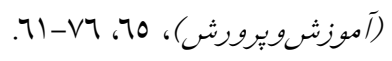

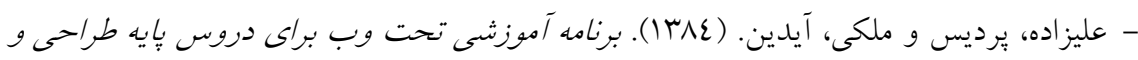

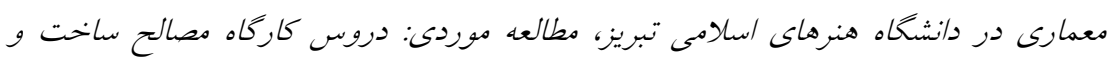

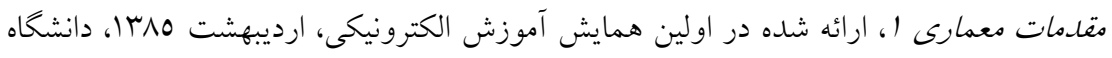
زنجان.

- كماليان، امين رضا و فاضل، امير. (1YMM). بررسى بيشنيانها و و امكانسنجى اجراى نظام

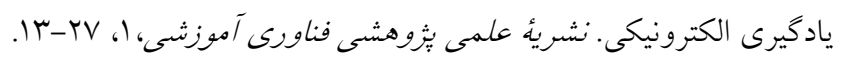

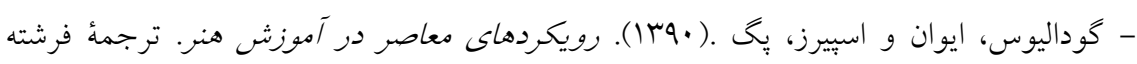
صاحبققلم. تهران: نظر.

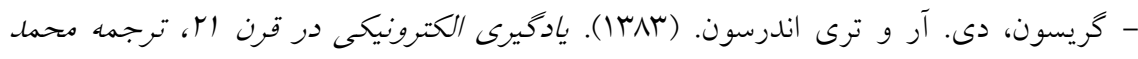

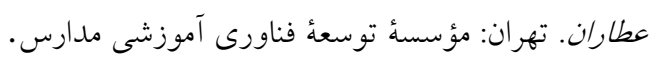

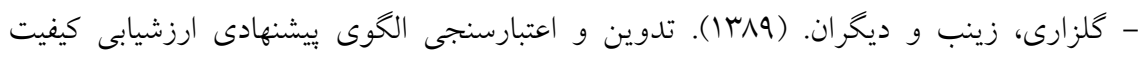

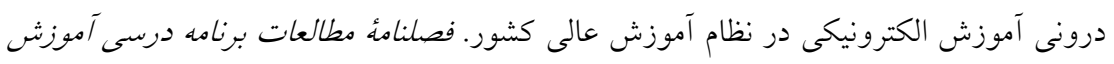

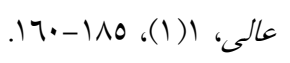

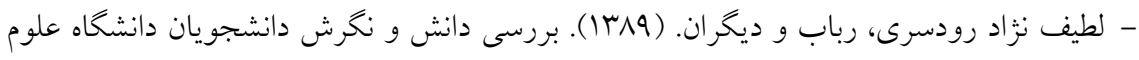

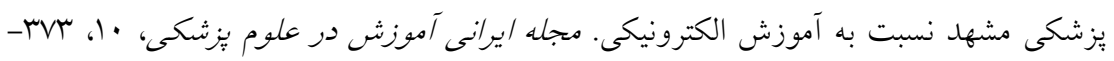
ع

- ماجد اسماعيل، عبداله. (1) (1). محكى نمودن الزامات برقرارى آموزش الكترونيكى در دانشكاه

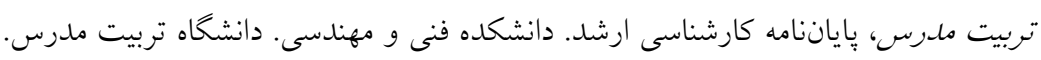

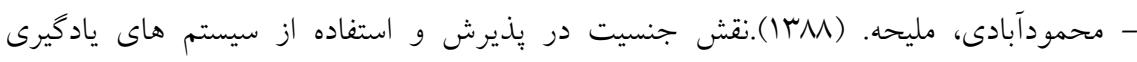

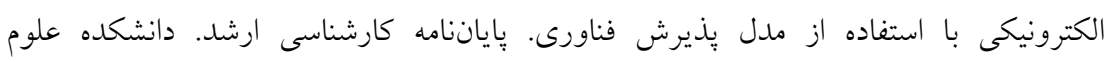
اجتماعى و اقتصادى، دانشخاه الزهرا

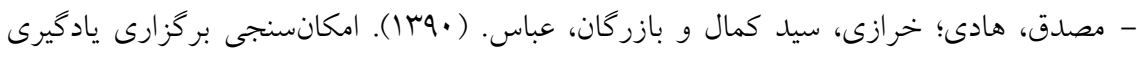

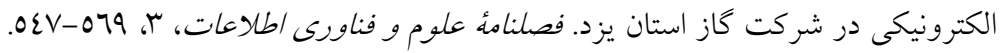




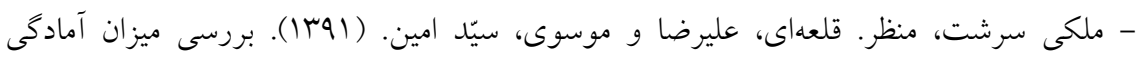

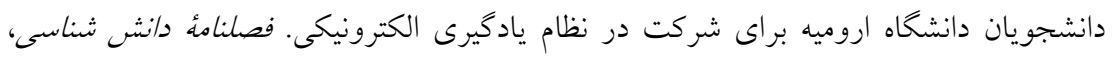
. ITr-IEY، IN

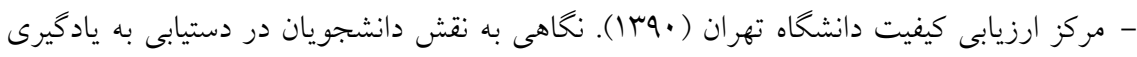
عميق. در لينك مذكور موجود است:

http://cuqa-learning.ut.ac.ir/file.php/1/students_90.7.9_doc(2015,sep 11)

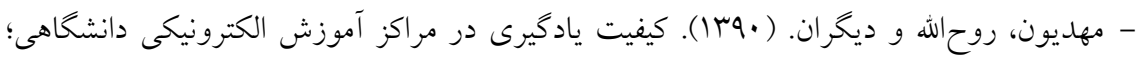

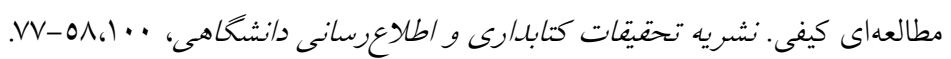

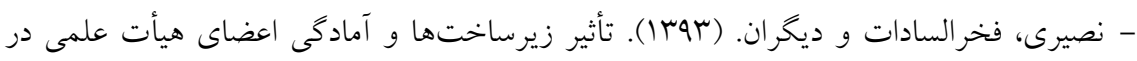

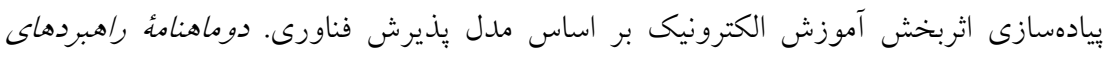

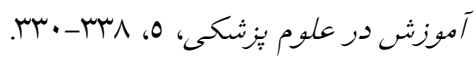

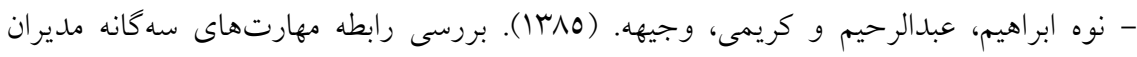

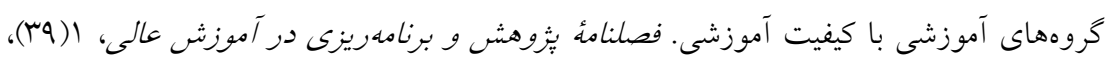
$.71-V \Lambda$

- Alem, F. (2014). Students Online Readiness Assessment Tools: A Systematic Review Approch. The Electronic Journal of e-Learning, 12(4), 375-283.

- Aydin C.H. and Tasci D. (2005). Measuring Readiness for e-Learning: Reflections from an Emerging Country, ducational Technology \& Society, 8, 244-257.

- Barry, Nancy. H. (2003). Integrating web Based learning and instruction into a raduate music education research course: An exploratory study. Journal of Technolog' in Music Learning, 2(1), 2-8.

- Belmont, J. M. (1998). Cognitive Strategies and Strategic Learning. American Psychology Journal, 44(2), 42-48.

- Birch,D. (2001). e-Learner Competencies.Retrived;at 11 sep 2015, from:

http://www.sdl_demo.s3.amazonaws.com/89/www/24328/1/1.pdf 
بررسى ميزان آمادكى دانشجويان هنر براى شركت در...

- Bonanno, P. (2011). Developing an Instrument to Assess Teachers` Readiness for Technology-Enhanced Learning. In: $14^{\text {th }}$ International Conference on Interactive Collaborative Learning (ICL 2011). Piestany, Slovakia, September 21-23.

- Chan. L. M. Y, Jones. A.C, Eileen. S \& Richard.J. (2006). The use of ICT to support the development of practical music skills through acquiring keyboard skills: a classroom based study. Computers \& ducation, 46, 391-406.

- Chu. R.J.C \& Tsai.C.C. (2009). Self-directed learning readiness, Internet self-efficacy and preferences towards constructivist Internetbased learning environments among higheraged adults. Journal of Computer Assisted Learning, 25, 489-501.

- Dabbagh, N. (2007). The online learner: Characteristics and pedagogical implications. Contemporary Issues in Technology and Teacher Education, 7(3), 217- 226.

- Gordon O. Ouma et al. (2013), E-Learning Readiness in Public Secondary Schools in Kenya.European Journal of Open, Distance and e-Learning, 16, 97-110.

- Harapnuik, D. (2006). Inquisitivism: The evolution of a constructivist approach for web-based instruction. In Sorensen, K.E., Murchu,D. Enhancing learning through technology. London: Information science publishing.

- Hasmi, M. \& Asaari, A. H. (2005). Adult Learners And E-Learning Readiness: A Case Study. European College Teaching \& Learning Conference Athens, Greece.

- Hung, M.L., Chou,C.H., Chen, C., \& Own, Z.Y. (2010). Learner Readiness for Online Learning: Scale Development and Student Perception. Computers \& Education, 55, 1080-1090.

- Hussen Ali, I. E. (2010). Measuring Students E-readiness for ELearning at Egyptian Faculties of Tourism and HotelS. The $6^{\text {th }}$ International Scientific Conference eLearning and Software for Education. Bucharest. April 15-16. 
- Huang.R.T. (2009). Factors that influence online learners intent to continue in an online graduate program.Un published dissertation. Louisiana State University.

- Jariangprasert, N. (2003). The Opinion of Faculty of Business Administration Lecturers and Students; Chiang Mai University about the Use of E-Learning. Social Sciences \& Humanities, 9(2), 136-145.

- Johnson. D., Patton. R., Bimber. B., Almeroth. K., \& Michaels. G. (2004). Technology and Plagiarism in the University: Brief report of a Trial in Detecting Cheating. AACE Journal, 12(3). 281-299.

- Kaur, K. \& Abas, Z.W. (2004). An Assessment of E-Learning Readiness at the Open University Malaysia.In International Conference on Computers in Education, 1017-1022.

- Khan. H. (2005). Managing E-Learning: Design, Delivery, Implementation and evaluation. USA: The George Washington University.

- Liaw, S. S. \& Huang, H. M. (2003). An Investigation of Users Attitudes toward Search Engines as an Information Retrieval Tool. Computers in Human Behavior, 19(6), 751-765.

- Liaw S.S. (2004). Consideration for Development Constructivist WebBased learning. International Jurnal of Instructional Media, 31, 309321.

- Meece, J. L., Bluemenfeld, P. C. and Hoyle, RH. (1998). Student Goal Orientations and Cognitive Engagement in Classroom Activities. Journal of Education Psychology, 80(4), 415-523.

- Mercado, Cecilia A. (2008), Readiness Assessment Tool for An eLearning Environment Implementation, Fifth International Conference on eLearning for Knowledge-Based Society, December 1112. Bangkok, Thailand.

- Miguel, B., Mc pherson, M. (2004). Developing Innovationin Online Learning.London: Routledgfalmer. 
بررسى ميزان آمادكى دانشجويان هنر براى شركت در...

- Moftakhari, M.M. (2013). Evaluating E-larning Readiness of Faculty of Letters of HACETTEPE. Unpublished master`s Thesis. Hacettepe University. Ankara.

- Morrison, G.R; Ross, S. M\& Kemp.J.E. (2004). Designing Effective Instruction. New Jersey:John Wiley.

- Palloff, R., \& Pratt, K. (2003). The Virtual Student. San Francisco: Jossey-Bass.

- Piskurich, G. M. (Ed.) (2004). Getting the Most from Online Learning. San Francisco, USA: Pfeiffer.

- Pingle Sudha S. (2011). Higher education students readiness for Elearning. An nternational Journal of Educational Technology, 4, 155 165.

- Pratt. K., Pallof. M. R. (2005). Collaborating Online: Learning Together in Community. San Francisco, CA: Jossey - bass.

- Rezaeian.A. et al. (2013). Feasibility study of implementing e-learning and knowledge management related to PNU Iran. Reef Resources Assessment and Management Technical Paper, 4, 119-123. Available online at www.behaviorsciences.com -content/uploads/2013/11/7shirazipour.pdf

- Rhode.J.F. (2004).Roles \& Responsibilities of the Online Learner. Retrived 12 june 2009from:www.Slide share. Net.

- Robertson, I. (2007). Technology-based learning: Problematising VET students' preferences and readiness. AVETRA Conference, 11-13 April 2007, Victoria University.

- Sadik, A. (2007). The readiness of faculty members todevelop and implement ELearning:The case of an Egyptian university, International Journal of ELearning, 6(3), 433-453.

- Santy, J. Smith,L. (2007). Being an e-learner in health and social care: Astudents guide. London:Routledge. 
- Schleifer, Lydia L. F. and Dull, Richard B. (2009). Meta Cognition and Performance in the Accounting Classroom. Issues in Accounting Education, 24(3),,339-367.

- Shih, C., T. Ingebritsen, J. Pleasants, K. Flickinger, and G. Brown, G. (1998). Learning strategies and other factors influencing achievement via Web courses. Proceedings of the 14th Annual Conference on Distance Teachingand Learning (359-363). Madison, WI. (ED 422876)

- So, K.K.T. (2005). The E-Learning Readiness of Teachers in Hong Kong. In: Proceedings of the Fifth IEEE International Educational Technology Conference. Anadolu University. Turkiey.

- Soydal, İ., Ünal, Y. ve Alır, G. (2011). Are Turkish universities ready for e-learning: A case of Hacettepe University Faculty of Letters. Information Services \& Use, 31 (), 281-291

- Tsai. M.J. (2009). The Model of Strategic e-Learning: Understanding and Evaluating Student e-Learning from Metacognitive Perspectives. Educational Technology \& Society, 12 (1), 34-48.

- Watkins,R., Leigh, D.\& Triner,. D. (2004). Assessing Readiness for ELearning. Performance Improvement Quarterly, 17(4), 66-79.

- Yang, Chunyan. (2005). Learning Strategy Use of Chinese PhD Students of Social Sciences in Australian Universities. GriffithUniversity, Doctoral Dissertation.

- Yukselturk. E. \& Bulut, S. (2007). Predictors for Student Success in an Online Course. Educational Technology \& Society.10 (2), 71-83.

- Zimmerman, B. J. and Martinez-pons, M. (1990). Student Differences in Self-regulated Learning: Relating Grade, Sex, and Giftedness to Self efficacy and Strategy Use. Journal of Educational Psychology, 82, 5159. 